\title{
Implementation of the
}

\section{Fish \& Wildlife}

Alberta Piping Plover Recovery Plan, 2005-2010: Division Final Program Report

\section{SPECIES AT RISK}

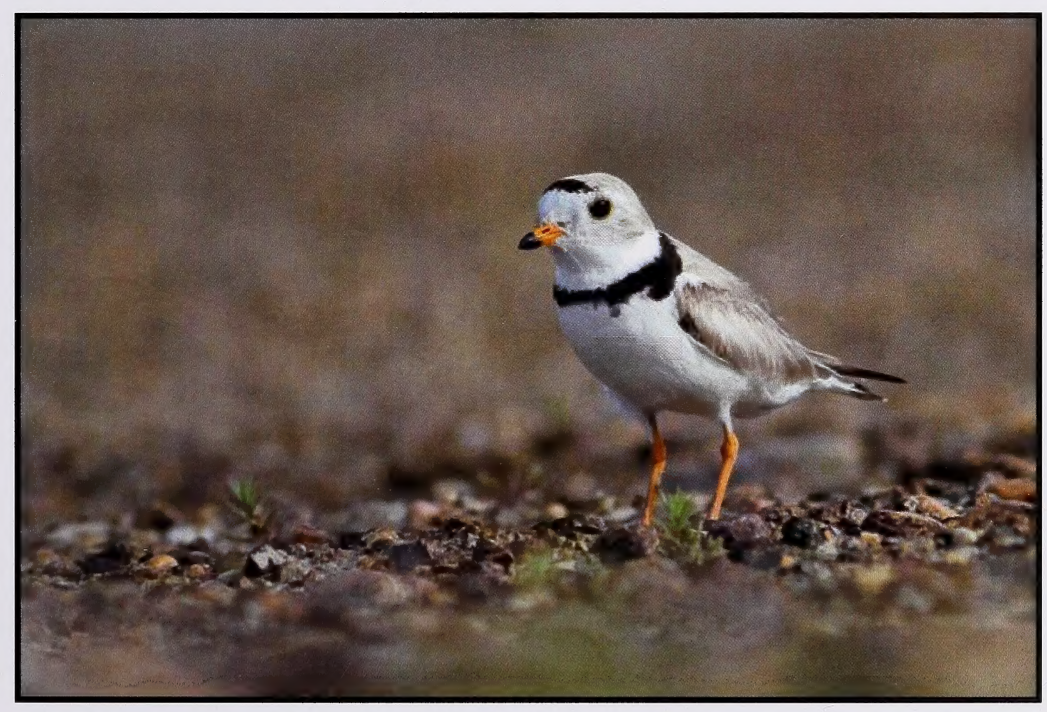

Government of Alberta

Alberta Species at Risk Report No. 129 
Digitized by the Internet Archive in 2016 


\title{
Implementation of the Alberta Piping Plover Recovery Plan, 2005-2010: Final Program Report
}

\author{
David R. C. Prescott ${ }^{1}$ \\ Lance C. Engley ${ }^{2}$ \\ Dan Sturgess $^{2}$
}

\footnotetext{
${ }^{1}$ Alberta Sustainable Resource Development, Fish and Wildlife Management Division, Red Deer, AB

${ }^{2}$ Alberta Conservation Association, Sherwood Park, AB
}

Alberta Species at Risk Report No. 129

March 2010 
Publication No.: I/430

ISBN: 978-0-7785-9020-0 (Printed Edition)

ISBN: 978-0-7785-9021-7 (Online Edition)

ISSN: 1496-7219 (Printed Edition)

ISSN: 1496-7146 (Online Edition)

Cover Photograph: Dave Prescott

For copies of this report, contact:

Information Centre - Publications

Alberta Environment / Alberta Sustainable Resource Development

Main Floor, Great West Life Building

9920108 Street

Edmonton, Alberta, Canada T5K 2M4

Telephone: (780) 422-2079

\section{OR}

Visit our web site at:

http://srd.alberta.ca/BioDiversityStewardship/SpeciesAtRisk/Default.aspx

This publication may be cited as:

Prescott, D. R. C., L. C. Engley, and D. Sturgess. 2010. Implementation of the Alberta Piping Plover Recovery Plan, 2005-2010: Final Program Report. Alberta Sustainable Resource Development, Fish and Wildlife Division, Alberta Species at Risk Report No. 129, Edmonton, AB. 27 pp. 


\section{TABLE OF CONTENTS}

LIST OF TABLES .........................................................................................................................

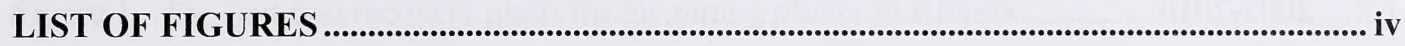

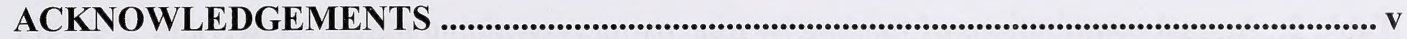

EXECUTIVE SUMMARY ....................................................................................................... vi

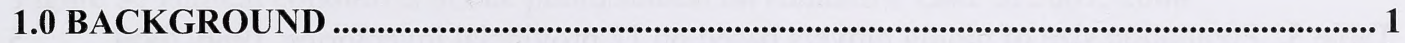

2.0 PLAN MANAGEMENT AND ADMINISTRATION ...................................................... 2

2.1 Recovery Team

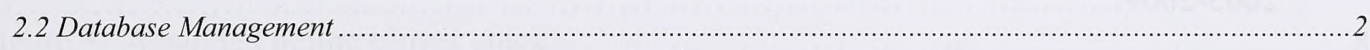

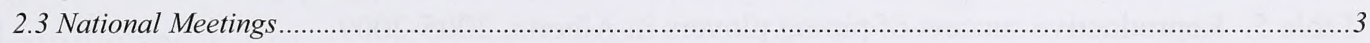

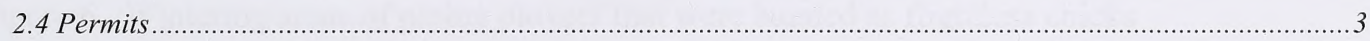

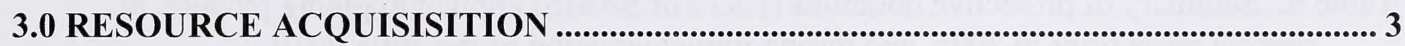

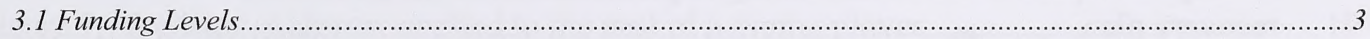

4.0 POPULATION MONITORING AND RESEARCH ...................................................... 4

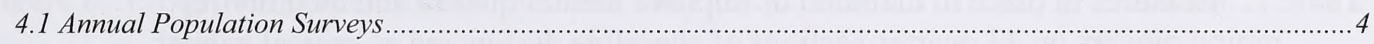

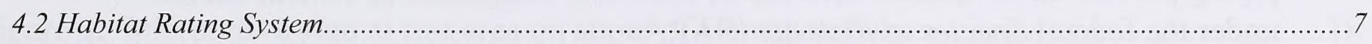

4.3 Remote Predator Surveillance .............................................................................................................

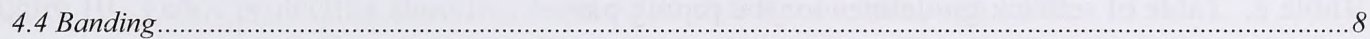

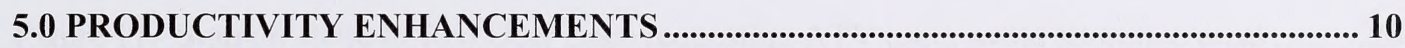

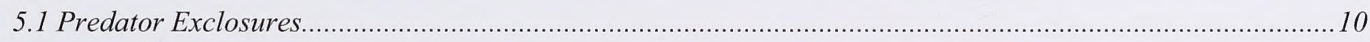

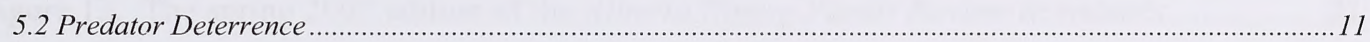

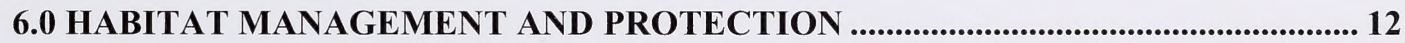

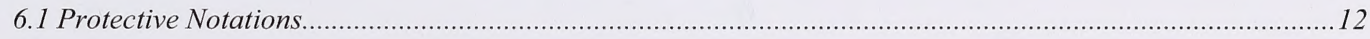

6.2 Critical Habitat Designation and Protection....................................................................................

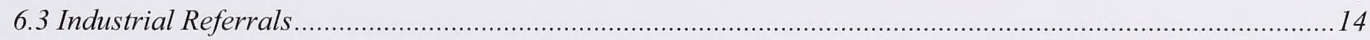

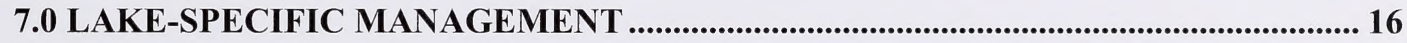

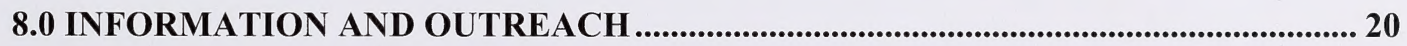

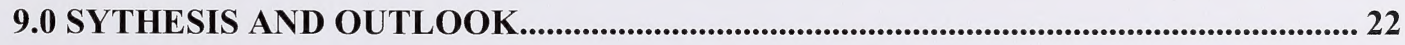

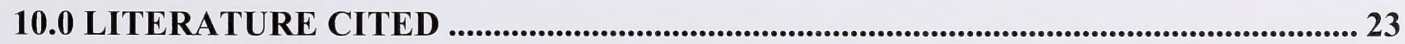

APPENDIX 1: IMPLEMENTATION SCHEDULE AND COSTS (from Alberta Piping Plover Recovery Plan, 2005-2010) ...................................................................................... 27 


\section{LIST OF TABLES}

Table 1. Financial contributions of nine partners to piping plover recovery in Alberta, 2005-2010

Table 2. Annual contributions of funding by nine partners to piping plover recovery in Alberta.

Table 3. Population size of piping plovers based on 12 provincial inventories, 1986-2009 5

Table 4. Populations of piping plovers counted during annual surveys in Alberta, 2005-2009 6

Table 5. Reproductive success of piping plovers in Alberta, 2005-2009

Table 6. Summary of protective notations (PNTs or SAMS) applied to piping plover nesting areas prior to 2005, and during implementation of the 2005-2010 recovery plan.

Table 7. Measures in place to maintain or improve habitat quality and quantity for piping plovers on 43 quarter-sections of shoreline designated as critical habitat under the federal Species at Risk Act (SARA).... 15

Table 8. Table of setback guidelines for the piping plover. 16 


\section{LIST OF FIGURES}

Figure 1. The first two recovery plans for the piping plover in Alberta 1

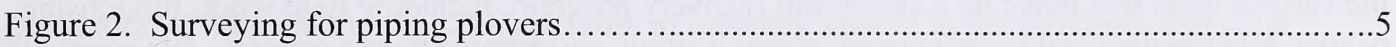

Figure 3. Habitat conditions at one photo station on Handhills Lake in 2007, 2008 and 2009

Figure 4. A coyote attempts to depredate a plover nest inside an exclosure .8

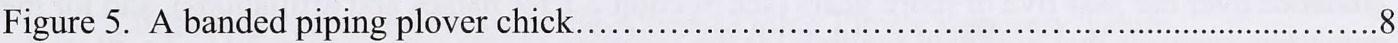

Figure 6. Wintering areas of piping plovers that were banded as flightless chicks in Alberta, 1996-2009

Figure 7. Predator exclosure applied to the nest of a piping plover......................... 10

Figure 8. Electrified predator fence on Clark Lake.........................................12

Figure 9. Interpretive sign at rest area on shore of Hansman Lake...........................18

Figure 10. Fence protecting shoreline from cattle damage on McLaren Lake...................19

Figure 11. Sign on shore of Red Deer Lake requesting ATV users avoid shoreline areas........20

Figure 12. The spring 2007 edition of the Alberta Piping Plover Review newsletter................21 


\section{ACKNOWLEDGEMENTS}

The management and recovery of piping plovers in Alberta has involved a large number of supporters and participants over the past five years. Naming these people individually would no doubt to lead to many omissions. Rather, we will generically thank all those who helped with the various tasks that make up a successful recovery program, including field work, fundraising, habitat development and improvement, report writing, and administrative support. We especially thank our dedicated field crews, the landowners that allowed access across their properties and participated in cooperative projects, and the industrial developers that altered their activities to accommodate plovers.

We particularly thank the members of the Alberta Piping Plover Recovery Team for their guidance over the past five or more years (see Section 2.1 for names and affiliations), and for the numerous agencies that provided funding for the recovery efforts (see Section 3.1). To all, and other groups we have already overlooked, we are grateful. 


\section{EXECUTIVE SUMMARY}

The piping plover (Charadrius melodus) is an endangered species in Alberta. In 2001, the Alberta Piping Plover Recovery Team was formed, and an inaugural recovery plan (2002-2004) was launched. An updated plan, with similar goals, strategies and activities was drafted in 2005. These recovery plans describe a variety of actions necessary to achieve: (1) a provincial population of 300 adult birds, (2) no net loss of breeding habitat in the province, and (3) a median fledging rate of 1.25 chicks/pair/year. This report summarizes activities completed during implementation of the Alberta Piping Plover Recovery Plan, 2005-2010, and sets the stage for a new recovery plan to be drafted in 2010 .

Major accomplishments achieved between 2005 and 2010 that are detailed in this report include:

- Convening of four meetings of the Alberta Piping Plover Recovery Team

- Maintenance of several databases that support plover management activities and track accomplishments

- Participation of the team leader, or his delegate, at all annual meetings of the Prairie Piping Plover Recovery Team

- Securement of $\$ 821,267$ in cash support from nine funding partners, and additional "inkind" support estimated to be well in excess of $\$ 275,000$

- Completion of annual population surveys, including coordination and participation in the Alberta portion of the International Piping Plover Census in 2006

- Discovery of plovers on a lake where breeding was previously unknown (Mott Lake)

- Attainment of a breeding population of 295 birds in 2008, which is just below the recovery target of 300 birds

- Development of a system to track habitat quality and threats in the province

- Use of remote cameras to document predators of piping plover nests

- Banding of 174 chicks over five years, and tabulation of 686 encounters with banded birds since 1996

- Discovery of 599 piping plover nests since 2005. Predator exclosures were applied to over $90 \%$ of these nests, resulting in the production of over 1000 more chicks than would have hatched from unprotected nests

- Fledging of 1.19 chicks/pair/year, which is below the target value of 1.25 chicks/pair/year. The calculated value is very conservative, and target levels were probably achieved in most years

- Use of electrified predator fences on two lakes to enhance productivity

- Placement of protective notations (PNTs or SAMS) on 100 quarter sections of habitat on 28 lakes

- Implementation of a wide variety of management options to protect habitat on 43 quarter sections of land on 13 lakes that are designated as "critical habitat" under the federal Species at Risk Act

- Participation in numerous industrial referrals to ensure that disturbance to breeding piping plovers and their habitat is minimized 
- Completion of a variety of information and education initiatives (cottager surveys, landowner visits, preparation and distribution of newsletters, erection of signage, etc.) to inform the public and to gain support for plover management.

We are confident that recovery goals can be achieved with ongoing management, which includes the maintenance of existing projects and relationships, and the implementation of new initiatives. Although there are a variety of management tools available to benefit plovers, the threats of increased human disturbance and high predator populations cannot easily be mitigated. The piping plover will therefore require ongoing management in Alberta to ensure that populations do not decline in the future. 


\subsection{BACKGROUND}

The piping plover is a small shorebird that is listed as an "endangered" or "threatened" species throughout its' North American range. In Canada, the species is listed as "endangered" under the federal Species and Risk Act (SARA), and has been similarly listed under the Alberta Wildlife Act since 2000 (Alberta Piping Plover Recovery Team 2005, 2006).

Estimates derived from continent-wide surveys on the breeding and wintering grounds show that there are about 8000 piping plovers in the world (Haig and Plissner 1992, 1993, Haig et al. 2005, Elliott-Smith et al. 2009). In Alberta, where populations of 150 to 300 individuals occur (Prescott 1997, 2009), the species has been intensively managed for the past 15 years (Alberta Piping Plover Recovery Team 2005). This management has intensified in recent years, most notably with the formation of a provincial recovery team in 2000, and the approval of an inaugural recovery plan (Alberta Piping Plover Recovery Team 2002; Figure 1) in 2002. Accomplishments achieved under that plan have been reported in detail (Alberta Piping Plover Recovery Team 2005). In 2005, an updated recovery plan, which covered the period from 20052010 was produced (Alberta Piping Plover Recovery Team 2006; Figure 1). This plan was approved for implementation by the Minister of Sustainable Resource Development in June 2006. The provincial plan was designed to integrate with the national recovery strategy for the prairie (circumcinctus subspecies) piping plover (Environment Canada 2006). The Alberta Piping Plover Recovery Plan, 2005-2010 is currently being considered for adoption as an action

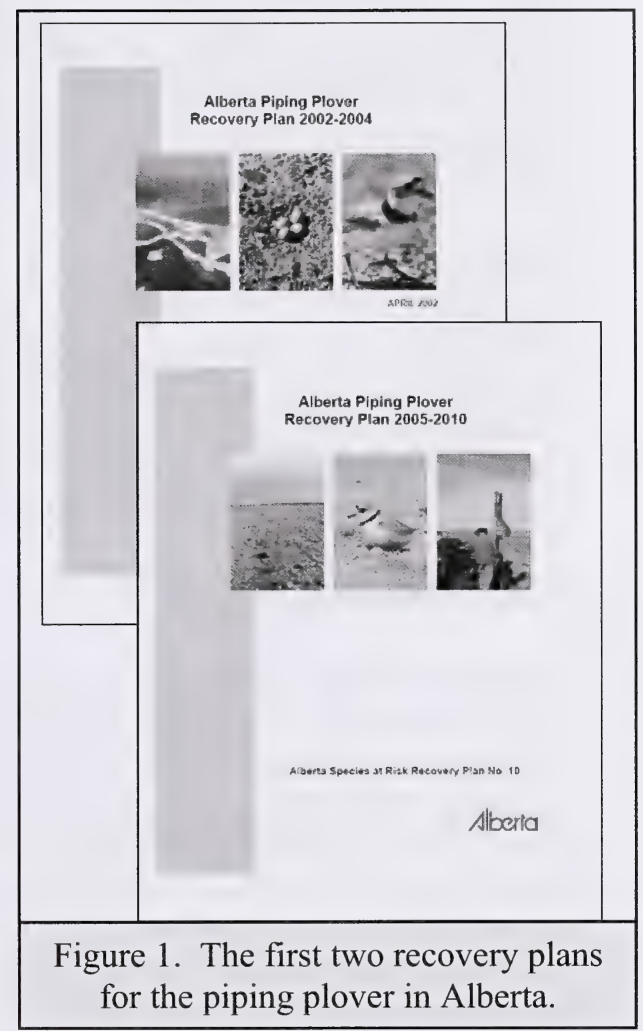
plan under the federal strategy (posted for public comment on 23 October 2009).

The overall goal of the current provincial recovery plan is "to achieve a well-distributed, longterm population of 300 individual piping plovers within their historical range in Alberta" (Alberta Piping Plover Recovery Team 2002, 2006). A wide variety of actions were proposed to achieve this goal. These actions, which are reproduced in Appendix 1, fell under six broad strategies: Habitat Management and Protection, Productivity Enhancement, Information and Outreach, Population Monitoring and Research, Plan Management and Administration, and Resource Acquisition. In this report, we highlight accomplishments achieved during implementation of the Alberta Piping Plover Recovery Plan, 2005-2010, and look ahead to the future of piping plover management in this province. 


\subsection{PLAN MANAGEMENT AND ADMINISTRATION}

\subsection{Recoverv Team}

The Alberta Piping Plover Recovery Team convened four times during the implementation of this plan (3 October 2005, 5 October 2006, 15 January 2008, and 15 December 2009). The team has met a total of 10 times since 2001. The recent reduction in the frequency of meetings reflects the fact that plover management in Alberta has progressed well, and there have been few issues to resolve along the way. In general, the meetings were exchanges of information between members actively involved in the day-to-day management of plovers with other organizations represented on the recovery team. There were no significant issues tabled for team decisions. Not all members were present for all meetings.

Membership remained relatively static over the period, with the following members and organizations being represented: Alberta Sustainable Resource Development - Dave Prescott (Team Lead), Ed Hofman, Dave Moore (all Fish and Wildlife Division) and Gerry Haekel (Lands Division); Nature Conservancy of Canada - Tara Worobetz, replaced by Juanna Thompson in 2006; Alberta Conservation Association - Lance Engley; Ducks Unlimited Canada - Mike Barr; Alberta Beef Producers - Craig Horner; Special Areas Board - Dug Major; Canadian Wildlife Service- Paul Goossen.

\subsection{Database Management}

A variety of databases are maintained and populated with data collected during the piping plover recovery program. The primary repository for inventory data is the Fisheries and Wildlife Management Information System (FWMIS) that is maintained by Alberta Fish and Wildlife Division. The presence of piping plover records (and those of other species) in this database alerts provincial biologists and other users (such as consultants, industry representatives, academics and the public) to the presence of piping plovers on the landscape. This database is extensively queried when making land-use decisions. Since April 2005, a total of 1068 occurrences of piping plovers have been entered into the FWMIS system, and a total of 5339 records have occurred back to 1925 .

Alberta Fish and Wildlife, through the recovery team leader, also maintains a database specific to piping plovers and their management in Alberta. This database includes census data, nest locations and success, banding data, fledging success, landowner information, and management activities on piping plover habitat. This Microsoft Access ${ }^{\mathrm{TM}}$ database was initiated in 2006, and continues to be revised to improve data entry and retrieval functionality.

Records of birds banded under the program are submitted to the Canadian Wildlife Service on an annual basis. This submission is a requirement for obtaining an annual banding permit, and makes banding records accessible to researchers and other individuals. Since 2005, 174 records have been submitted to the Bird Banding Office in Ottawa for inclusion in the database. 


\section{$\underline{2.3 \text { National Meetings }}$}

The Prairie Piping Plover Recovery Team met annually during the period 2005-2010. The Alberta Piping Plover Recovery Team leader attended the meetings as jurisdictional representative in 2005 (21-22 September in Kenora, ON), 2006 (20-21 September in Drumheller, $\mathrm{AB}$ ), and 2007 (30 October in Edmonton, AB). Due to travel restrictions, the Alberta team leader was unable to attend meetings in 2008 (29-30 October in Regina, SK) and 2009 (29-30 in Winnipeg, MB). In November 2005, the Alberta Conservation Association became an official member of the PPPRT, and represented Alberta at meetings when the team leader was unable to attend.

\subsection{Permits}

An increasing number of permits are required to conduct management activities on piping plovers. This increase is due to the federal Species at Risk Act (SARA) that has placed additional accountability on biologists working with endangered and threatened species, and the recent requirement for biologists working in provincial parks and protected areas to hold research and collection permits. Annual permit applications and reporting currently include the following permits:

1. Provincial Research Permit (Alberta Sustainable Resource Development)

2. Provincial Collection Permit (Alberta Sustainable Resource Development)

3. Federal Bird Banding Permit (Environment Canada)

4. Provincial Parks Permit (Alberta Tourism, Parks and Recreation)

5. Scientific Take Permit (Environment Canada)

The administration of these permits is an increasingly taxing component of plover management in Alberta.

\subsection{RESOURCE ACQUISITION}

\subsection{Funding Levels}

The management of plovers has succeeded because of the generous support of a number of organizations and individuals. This support has come in the form of cash contributions (usually resulting from grant applications), as well as "in-kind" support of time and other resources. Cash support from nine partners totalled $\$ 821,267$ (estimated, as 2009-10 figures are not final at the time of writing) during implementation of the current plan (Table 1). Annual funding varied from a low of $\$ 137,048$ in 2005-6, to a high of $\$ 201,989$ in 2009-10 (Table 2). Most monies were secured through applications for funding made by the Alberta Conservation Association (ACA); these funds were subsequently administered by the ACA.

"In-kind" support of labour, materials, time, and other services over the five-year period is difficult to quantify, but is conservatively estimated at $\$ 275,000$. 
Table 1. Financial contributions of nine partners to piping plover recovery in Alberta, 20052010.

\begin{tabular}{lc}
\hline \multicolumn{1}{c}{ Partner } & Funding Contribution \\
\hline Alberta Fish and Wildlife Division & $2005-2010$ \\
Alberta Conservation Assocation & $\$ 154,000$ \\
Environment Canada (Canadian Wildlife Service) & $\$ 408,029$ \\
Environment Canada (Habitat Stewardship Program) & $\$ 7,000$ \\
TD Friends of the Environment & $\$ 151,418$ \\
Alberta Employment and Immigration (STEP Program) & $\$ 31,000$ \\
Endangered Species Recovery Fund & $\$ 14,221$ \\
Alberta Sport, Recreation, Parks and Wildlife Foundation & $\$ 40,600$ \\
Mountain Equipment Co-op & $\$ 3,000$ \\
\hline \multicolumn{2}{c}{ TOTAL } \\
\hline
\end{tabular}

Table 2. Annual contributions of funding by nine partners to piping plover recovery in Alberta.

\begin{tabular}{|c|c|c|c|c|c|c|}
\hline \multicolumn{7}{|c|}{ Year } \\
\hline & 2005-6 & 2006-7 & $2007-8$ & $2008-9$ & $2009-10$ & TOTAL \\
\hline Total funds & $\$ 137,048$ & $\$ 142,448$ & $\$ 171,529$ & $\$ 167,253$ & $\$ 201,989$ & $\$ 821,267$ \\
\hline
\end{tabular}

\subsection{POPULATION MONITORING AND RESEARCH}

\subsection{Annual Population Survevs}

Population surveys for piping plovers are coordinated by the Alberta Conservation Association, and are conducted on an annual basis in Alberta. These surveys are primarily intended to monitor shifts in populations as lake conditions change, so that management can be directed to the areas with the greatest number of birds. Annual surveys are not intended to be complete provincial inventories. However the frequency of counts allows relatively close monitoring of habitat conditions. It is likely that these surveys count $>90 \%$ of the provincial population in any given year, and serve as a reasonable estimate of total population size in the province.

Every five years beginning in 1991, the International Piping Plover Census is conducted across the breeding and wintering ranges of the piping plover in North America. In Alberta, the survey is coordinated by the Alberta Fish and Wildlife Division, and has been completed in all designated survey years $(1991,1996,2001$, and 2006). The survey is intended to be a complete provincial count. In 2006, 32 observers spent approximately 350 person-hours to survey $450 \mathrm{~km}$ of shoreline on 71 lakes in Alberta. Complete details on the 2006 census are provided by Prescott (2009) and Goossen et al. (2010). The next scheduled international census will be in 2011. 
Relatively complete counts (either annual counts or five-year international censuses) have been

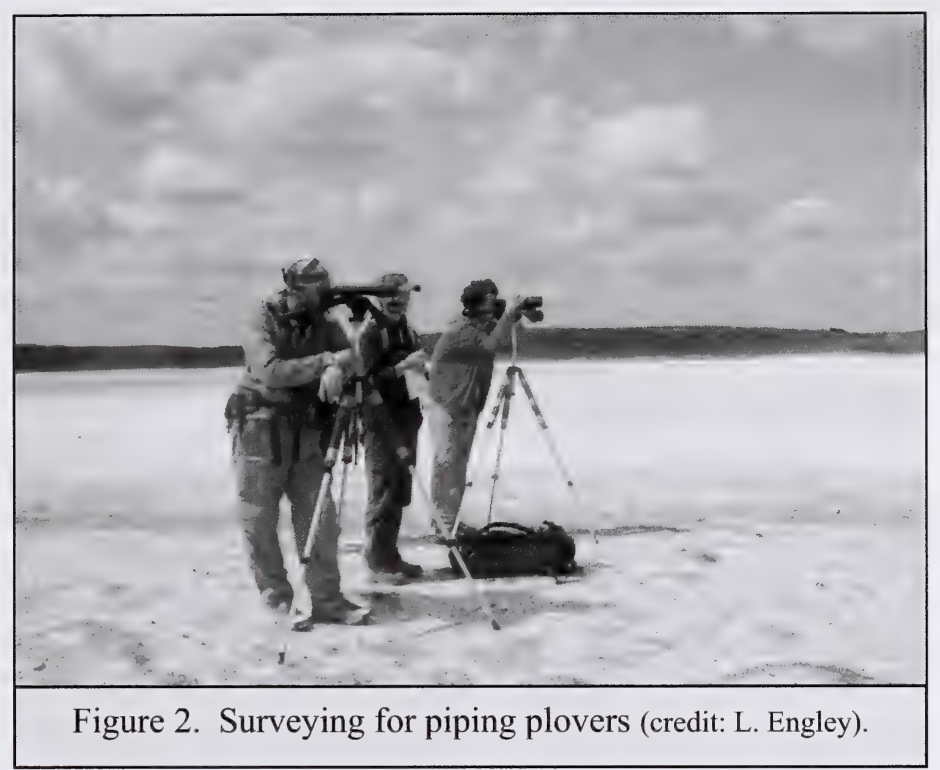
completed 12 times in Alberta since 1986, with the total provincial population ranging from a low of 134 birds in 2004 , to highs just below recovery target levels in 1986 (288 individuals) and 2008 (295 individuals; Table 3). A total of 86 lakes are known to have had plovers in Alberta (see Alberta Piping Plover Recovery Team [2006] for list of 85 lakes, and paragraph below for one addition). Typically, 20 to 25 lakes support birds in a given year, with three to six lakes supporting the majority $(>50 \%)$ of individuals (Table 3 ).

Table 3. Population size of piping plovers based on 12 provincial inventories, 1986-2009.

\begin{tabular}{cccccc}
\hline Year & $\begin{array}{c}\text { \# Lakes } \\
\text { Surveyed }\end{array}$ & $\begin{array}{c}\text { \# Lakes } \\
\text { With Birds }\end{array}$ & $\begin{array}{c}\text { Total } \\
\text { Birds }\end{array}$ & $\begin{array}{c}\text { Lakes with } \\
50 \% \text { of } \\
\text { Population }\end{array}$ & Source \\
\hline 1986 & $108+$ & 28 & 288 & 6 & Wershler and Wallis 1987 \\
1991 & 48 & 25 & 180 & 5 & Hofman 1994 \\
1996 & 103 & 31 & 276 & 4 & Bjorge 1997 \\
2001 & 126 & 23 & 150 & 5 & Prescott 2001 \\
2002 & 44 & 29 & 141 & 3 & Engley and Schmelzeisen 2002 \\
2003 & 33 & 23 & 152 & 3 & Schmelzeisen and Engley 2003 \\
2004 & 38 & 21 & 134 & 4 & Engley et al. 2004 \\
2005 & 27 & 22 & 206 & 6 & Schmelzeisen et al. 2005 \\
2006 & 70 & 25 & 274 & 6 & Rezansoff et al. 2006, Prescott 2009 \\
2007 & 28 & 21 & 273 & 5 & Van Huystee et al. 2007 \\
2008 & 27 & 22 & 295 & 6 & Rezansoff et al. 2008 \\
2009 & 26 & 24 & 215 & 6 & Rezansoff et al. 2009 \\
\hline
\end{tabular}

Since 2005, plovers have been found on 29 lakes in Alberta (Table 4). Only one of these lakes was not previously known to support plovers (Mott Lake). It is beyond the scope of this report to 
summarize all population shifts that have occurred since monitoring began in 1986. However, it is worthwhile to note the return of piping plovers to Handhills, Killarney and Dowling Lakes after several years of low numbers or absences, a reduction of birds at West Reflex, Little Fish and Muriel Lakes, and the emergence of Junction Lake as an important plover lake. This lake was previously known to have had birds only once prior to 2005 (a nesting pair in 1996).

Table 4. Populations of piping plovers counted during annual surveys in Alberta, 2005-2009. See Table 3 for data sources.

\begin{tabular}{|c|c|c|c|c|c|}
\hline \multirow[b]{2}{*}{ Lake } & \multicolumn{5}{|c|}{ Year } \\
\hline & 2005 & 2006 & 2007 & 2008 & 2009 \\
\hline Akasu & 9 & 12 & 15 & 16 & 9 \\
\hline Albert & 0 & 0 & 0 & - & - \\
\hline Baxter & 4 & 15 & 14 & 14 & 5 \\
\hline Beaverhill & 0 & 8 & - & - & 2 \\
\hline Birch & 12 & 22 & 23 & 17 & 15 \\
\hline Border & 0 & 1 & 1 & 2 & $2 *$ \\
\hline Chain 1 & 0 & 0 & - & - & - \\
\hline Chain 4 & 9 & 7 & 14 & 18 & 4 \\
\hline Chappice & - & 0 & 0 & - & - \\
\hline Cipher & 2 & 2 & 2 & 2 & 0 \\
\hline Clark & 9 & 9 & 3 & 7 & 15 \\
\hline Dowling & 4 & 8 & 38 & 24 & 7 \\
\hline Foster & 6 & 2 & 0 & 5 & 3 \\
\hline Frog & 15 & 12 & 4 & 15 & 9 \\
\hline Gooseberry & 0 & 0 & - & - & 2 \\
\hline Handhills & 9 & 17 & 23 & 36 & 36 \\
\hline Horseshoe & 8 & 8 & 14 & 16 & 6 \\
\hline Junction & - & 14 & 11 & 10 & 12 \\
\hline Killarney & 22 & 27 & 30 & 37 & 23 \\
\hline Leanne & - & - & 0 & - & - \\
\hline Little Fish & 4 & 4 & 2 & 0 & 5 \\
\hline McLaren & 8 & 6 & 8 & 10 & 9 \\
\hline Miquelon \#3 & - & 0 & - & $2 *$ & - \\
\hline Mott & 2 & 0 & 0 & 2 & 2 \\
\hline Muriel & 28 & 46 & 36 & 13 & 8 \\
\hline NW Killarney Pond & - & 6 & 9 & 9 & 4 \\
\hline Piper & 5 & 6 & 5 & 6 & 6 \\
\hline Plain & - & 1 & - & - & - \\
\hline Red Deer & 16 & 16 & 4 & 13 & 15 \\
\hline Rider & 5 & 1 & 0 & 0 & 1 \\
\hline Rockeling & & 0 & 0 & 0 & 0 \\
\hline Sunken & 7 & 7 & 4 & 10 & 4 \\
\hline West & 6 & 0 & - & - & - \\
\hline West Reflex & 16 & 17 & 13 & 13 & 13 \\
\hline TOTAL & 206 & 274 & 273 & 295 & 215 \\
\hline
\end{tabular}

* reported outside of recognized survey period and not included in annual total 


\subsection{Habitat Rating System}

The Alberta Piping Plover Recovery Plan, 2005-2010 called for the development of an objective system of rating habitat quality and threats in the province. In 2006, we developed a rating system, wherein quarter-sections of plover habitat are scored each year based on several attributes. "Natural" condition rated the potential of the habitat to support plovers, regardless of anthropogenic disturbances. At one extreme, quarter-sections were rated as "highly suitable" $($ score $=1$ ) based in the presence of wide beaches, abundant gravel and proximity to water. At the opposite extreme, a score of 5 was assigned to areas with no potential to support plovers. Intermediate values $(2,3,4)$ were assigned to conditions between these extremes. Ratings were also provided for various anthropogenic threats (cattle grazing, ATV traffic, human foot travel, other) on a scale of 1 (no threat) to 5 (extreme habitat impact).

The assignment of score to quarter sections began in 2007. However, difficulties were soon encountered with the system. Specifically, ratings could change markedly from visit to visit. Because different shorelines were visited a varying number of times in each year (and sometimes not at all), the application of ratings was highly inconsistent. These data have been collected incidentally over the past several years, but no tabulation of information has yet occurred.

The use of photo stations (Figure 3) was initiated as an alternative means if tracking habitat condition in 2005. In that year, stations were set up on six lakes at areas of disturbance. These photo stations are visited annually to capture any changes in the severity of disturbance from year to year. In 2006, photo stations were added to two more plover lakes with disturbed shoreline areas.

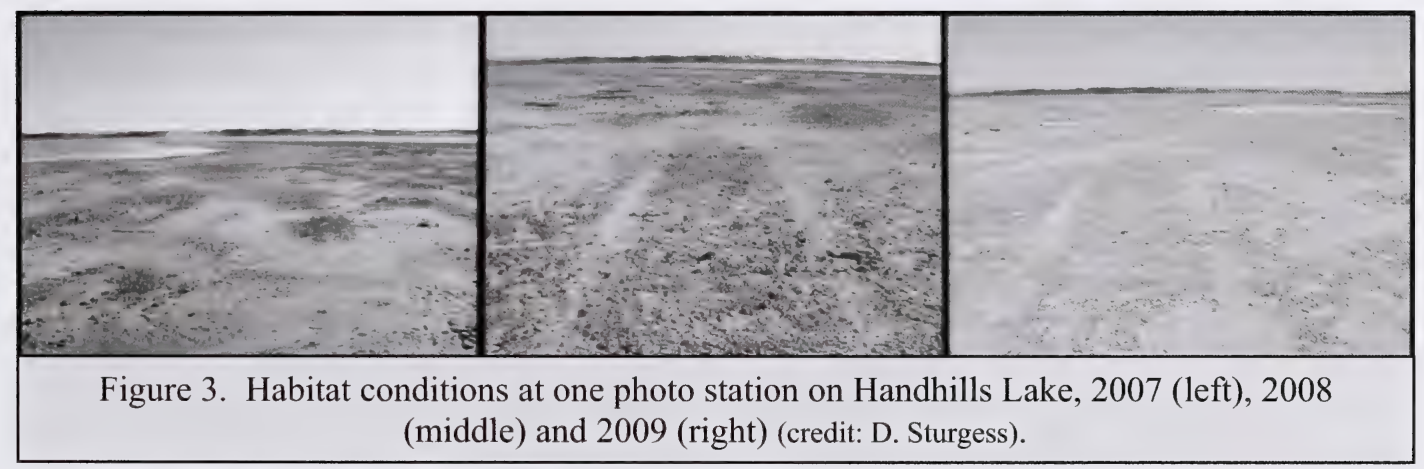

\subsection{Remote Predator Surveillance}

Predation on nests is the single biggest influence on productivity of piping plovers, yet the specific predators of eggs are poorly documented. Starting in 2005, we deployed three Reconyx ${ }^{\mathrm{TM}}$ cameras to record activity at plover nests, in hopes of documenting depredation events (successful or attempted) at exclosed nests. Each year, cameras were deployed on 5-6 different nests. Several attempted depredations by American crows and coyotes (Figure 4) were noted, and the destruction of a nest by an all-terrain vehicle was captured on film. We also used 
cameras to determine whether cattle or predators were being deterred from nesting beaches where electrified predator fences were installed (Clark and Piper Lakes). Several incidences of cattle being repelled by the fence were recorded.

In November 2009, six additional cameras were purchased for the Alberta program by the Canadian Wildlife Service. The use of these cameras will greatly enhance our ability to monitor activity at nests in the future.

\subsection{Banding}

The original goal of the banding program was to determine movements of birds from breeding areas to wintering grounds, between breeding areas from year to year, and to monitor survivorship. In more recent years, banding has been conducted primarily to allow distinction between broods of chicks, so

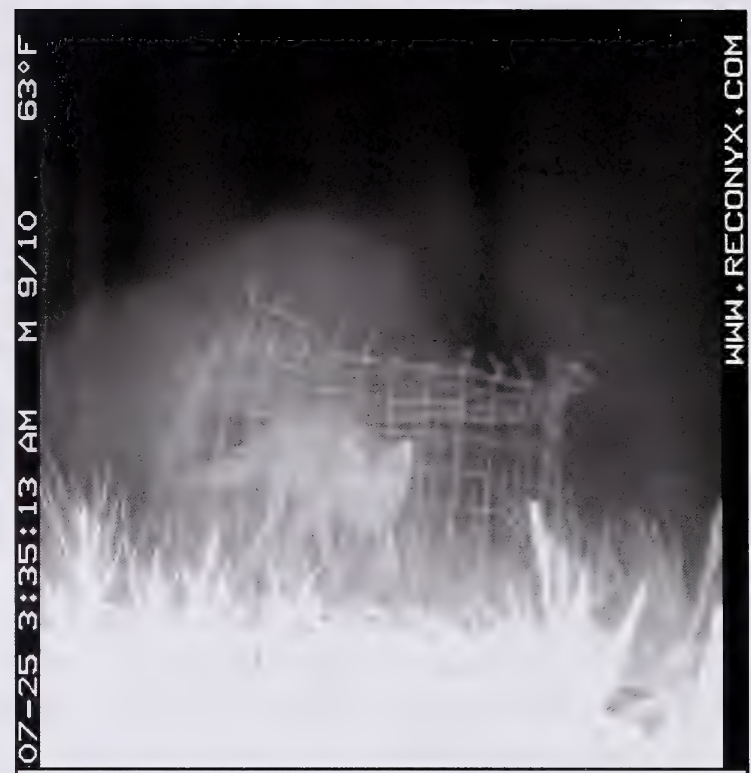

Figure 4. A coyote attempts to depredate a plover nest inside an exclosure (credit: L. Engley).

that survival of chicks can be determined (ultimately to calculate annual productivity, see Section 5.1).

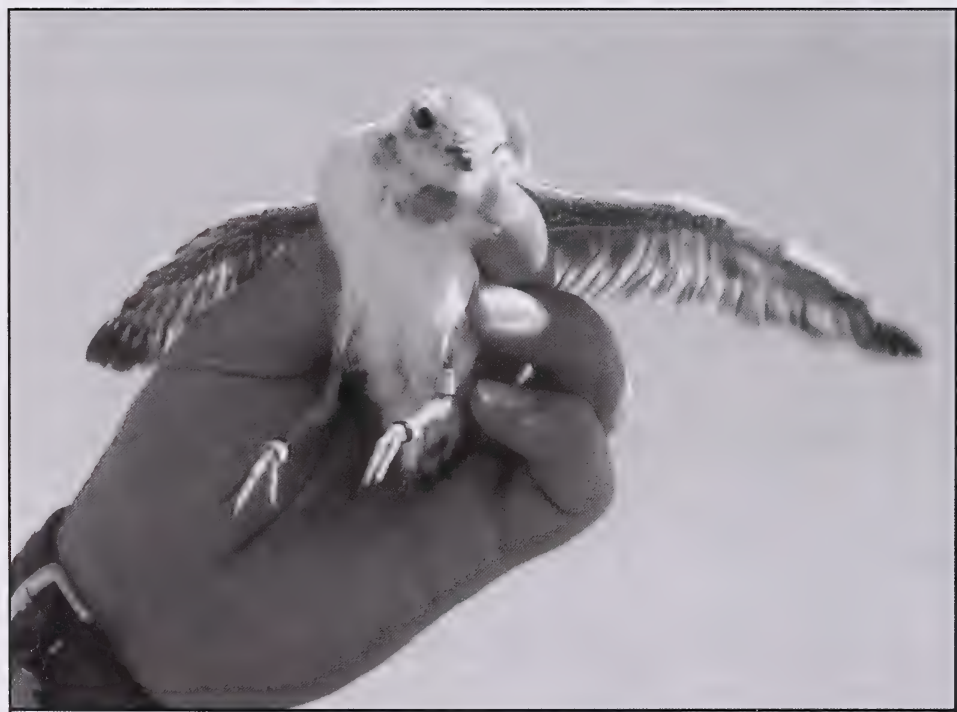

Figure 5. A banded piping plover chick (credit: L. Engley).
Banding has been ongoing since 1996, and a total of 879 birds have been banded through to 2009. With a small number of exceptions $(<1 \%$ of total), banding has been limited to chicks (Figure 5). The number of birds banded has declined in recent years for a variety of reasons (high band loss rates, original objectives being largely met, increased effort on other components of the field program,), but chicks are still banded on an opportunistic basis. Between 2005 and 2009, 174 chicks were color banded. 
Through November 2009, there have been 686 encounters with banded birds, with 504 of these occurring between 2005 and 2009. Most (326) of these 686 encounters were of birds banded in

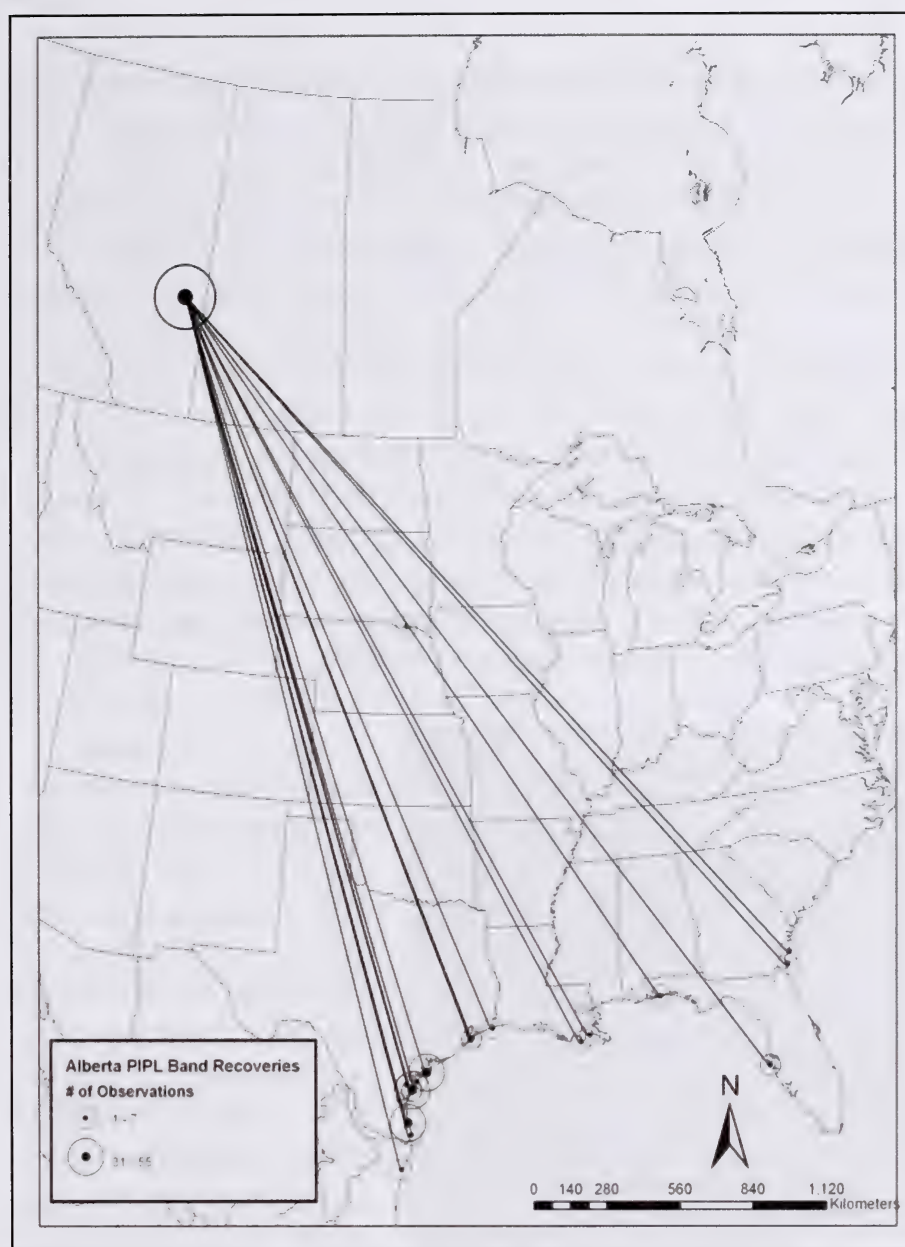

Figure 6. Wintering areas of piping plovers $(n=188)$ that were banded as flightless chicks in Alberta, 1996-2009.
Alberta and observed in subsequent years in Alberta (or nearby Saskatchewan lakes surveyed and banded by Alberta crews), with 230 being of local birds being reported elsewhere in North America. Of these, 42 were noted on the breeding grounds in Saskatchewan, with nine of these returning to Alberta to breed in later years. The remaining 188 foreign recoveries were observations of Alberta-banded birds seen on the wintering grounds or on migration. Chicks banded in Alberta were found mainly in Texas ( $86.2 \%$ of recoveries), with small numbers being scattered from northern Mexico to Georgia (Figure 6). Only two birds were recorded on migration (South Dakota and Iowa). We also encountered 67 birds that were banded elsewhere, with 57 of these records being birds banded in Saskatchewan that moved to Alberta to breed. The remaining 10 were individuals banded in Texas during the winter that nested in Alberta in subsequent years.

Piping plovers are intensively managed in many areas of the Great Plains. Despite the large number of potential observers, and the presence of a substantial banding program in the adjacent U. S. states (and elsewhere in North America), no Alberta-banded piping plovers have ever been sighted outside of Alberta or Saskatchewan during the breeding season, nor have any U.S.banded birds been found in this province. These results show that piping plovers disperse relatively small distances from their natal lakes, and that the management of populations and habitats in Alberta will have direct benefits for the provincial population. 


\subsection{PRODUCTIVITY ENHANCEMENTS}

\subsection{Predator Exclosures}

High levels of nest depredation have long been identified as the main factor limiting the size of piping plover populations (Larson et al. 2002, Elliott-Smith and Haig 2004). The primary method of mitigating this impact is through the use of predator exclosures. These simple structures are built with wire mesh of a size that allows adult birds to freely move between the spaces, but which restrict access to the nest by larger predators. Although several sizes and designs have been used in Alberta since the mid-1990s, all versions used since 2000 are built with a $2-\mathrm{m}$ length of stucco wire $\left(5-\mathrm{cm}^{2}\right.$ mesh) rolled into a circular shape with a resulting diameter of $60 \mathrm{~cm}$ and height of $40 \mathrm{~cm}$. The tops are covered with either soft nylon netting (2 $\mathrm{cm}^{2}$ mesh) or stucco wire (see Figure 7; a more complete description is provided in Schmelzeisen et al. 2005). Richardson (1999) showed that the use of predator exclosures in Alberta increases hatch success by $268 \%$. Researchers from elsewhere in North America have shown similar benefits (e.g., Rimmer and Deblinger 1990, Melvin et al. 1992, Maslo and Lockwood 2009). The Alberta Conservation Association has led the exclosure program since 1998, and since 2002, most ( $>90 \%$ ) nests found in Alberta have been covered with exclosures. Detailed procedures for exclosing nests are provided by Richardson (1997).

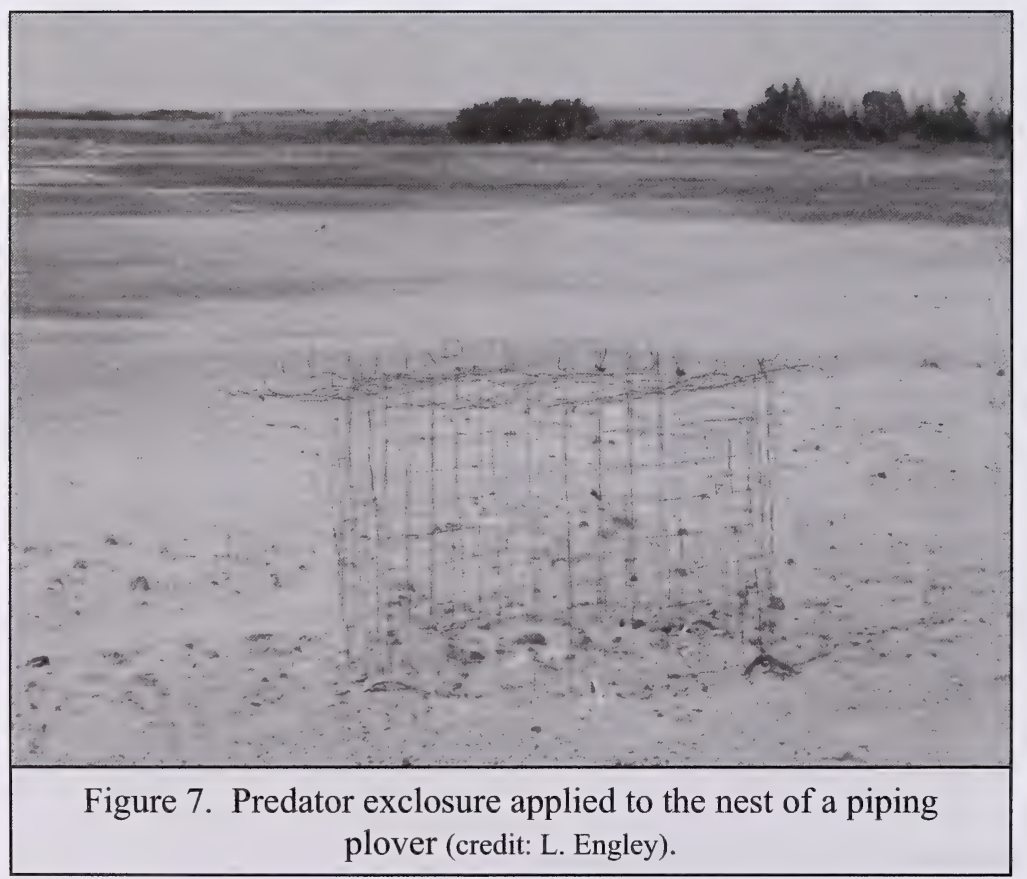

A total of 599 piping plover nests were found in Alberta between 2005 and 2009, with annual values ranging from 109 (2007) to 127 (2006). Of this total, $543(90.7 \%)$ were fitted with predator exclosures (range: 100 [2006] to 116 [2008]). A proper comparison of success between exclosed and unexclosed nests is difficult, given the relatively small number of unexclosed nests, the small number of associated "exposure days" required for calculation of Mayfield nest success (385 days vs. 10,808 days for exclosed nests), and the small number of unexclosed nests (19 of 56) where nest fate could be determined with confidence. Nevertheless, large differences in apparent nest success ( $85.0 \mathrm{vs.} 63.2 \%)$, and Mayfield nest success (77.9 vs. 52.6\%) suggest a clear advantage to exclosing nests in Alberta over the past five years. Assuming a clutch size of 3.93 eggs with natural hatchability of $92.7 \%$ 
(Table 5), the 543 exclosed nests would have produced 1541 hatchlings over the five-year period, compared to 1041 young had these nests not been exclosed (based on Mayfield success values).

Causes of nest failure were only known for six unexclosed nests, with five (83.3\%) of these being lost to predators (the other nest of known fate was abandoned). For exclosed nests, the cause of failure was reported in 75 instances. The two largest factors in nest failure were egg depredation (37.3\%) and unexplained abandonment (36.0\%), with egg infertility $(6.7 \%)$, destruction by all-terrain vehicles $(5.3 \%)$, attempted nest depredation and cattle ( $4.0 \%$ each), weather $(2.7 \%)$ and depredation on adult birds $(1.3 \%)$ making up the remainder.

Fledging success (probability of a chick reaching 20 days of age) ranged from $21.6 \%$ (2005) to $52.8 \%$ (2007), and averaged $35.3 \%$ over the five-year implementation period (Table 5).

Fledging success values for each year, combined with annual nest success estimates and other correction values (see Schmelzeisen et al. 2005 for details) yielded productivity estimates ranging from 0.73 (2005) to 2.02 (2007) chicks/pair/year. Productivity over the five-year period was calculated at 1.19 chicks/pair. This value is slightly lower than the targeted value of 1.25 chicks/pair recommended to increase populations on the Great Plains (Larson et al. 2000). However, the values calculated for Alberta are conservative, because fledging success is certainly underestimated (Schmelzeisen et al. 2005).

Table 5. Reproductive success of piping plovers in Alberta, 2005-2009.

\begin{tabular}{lcccccc}
\hline & 2005 & 2006 & 2007 & 2008 & 2009 & Total \\
\hline Total nests & 119 & 127 & 109 & 123 & 121 & 599 \\
Mean clutch size & 3.96 & 3.84 & 3.98 & 3.96 & 3.93 & 3.93 \\
\% eggs hatching & 94.5 & 91.7 & 91.1 & 92.5 & 93.9 & 92.7 \\
\% nest success & 83.8 & 86.9 & 91.1 & 82.2 & 77.1 & 82.5 \\
Nest Mayfield & 76.4 & 79.3 & 87.9 & 75.6 & 68.4 & 77.2 \\
Fledge Mayfield & 21.6 & 32.2 & 52.8 & 32.7 & 40.0 & 35.3 \\
Chicks/pair & 0.73 & 1.08 & 2.02 & 1.09 & 1.21 & 1.19 \\
\hline
\end{tabular}

\subsection{Predator Deterrence}

In 2006, an eight-wire E'Stop ${ }^{\mathrm{TM}}$ predator fence and Intellishock ${ }^{\mathrm{TM}}$ 42B fence energizer were purchased for use on lakes where nesting peninsulas could be isolated from the adjacent mainland with relatively short lengths of fence (Figure 8). These fences, particularly when used in conjunction with predator exclosures over nests, have been shown to be highly effective at decreasing nest depredation on piping plovers (Mayer and Ryan 1991, Murphy et al. 2003a). A second fence system was purchased in 2007. The system was deployed by the Alberta Conservation Association on Clark Lake in 2007, 2008 and 2009, and at Piper Lake between 
2006 and 2008 (the lake was dry in 2009 , so the peninsula could not be isolated by a single fence). The effectiveness of the fence is difficult to determine. However, we note that nest success on these lakes was $100 \%$ in years when the predator fence was erected, compared to $79.8 \%$ for all years combined. We also note that fledging success was $72.3 \%$ in years when the fence was used, compared to $46.5 \%$ for all years combined.

During the winters of 2005 , 2006 and 2007, field crews from the Alberta Conservation Association removed

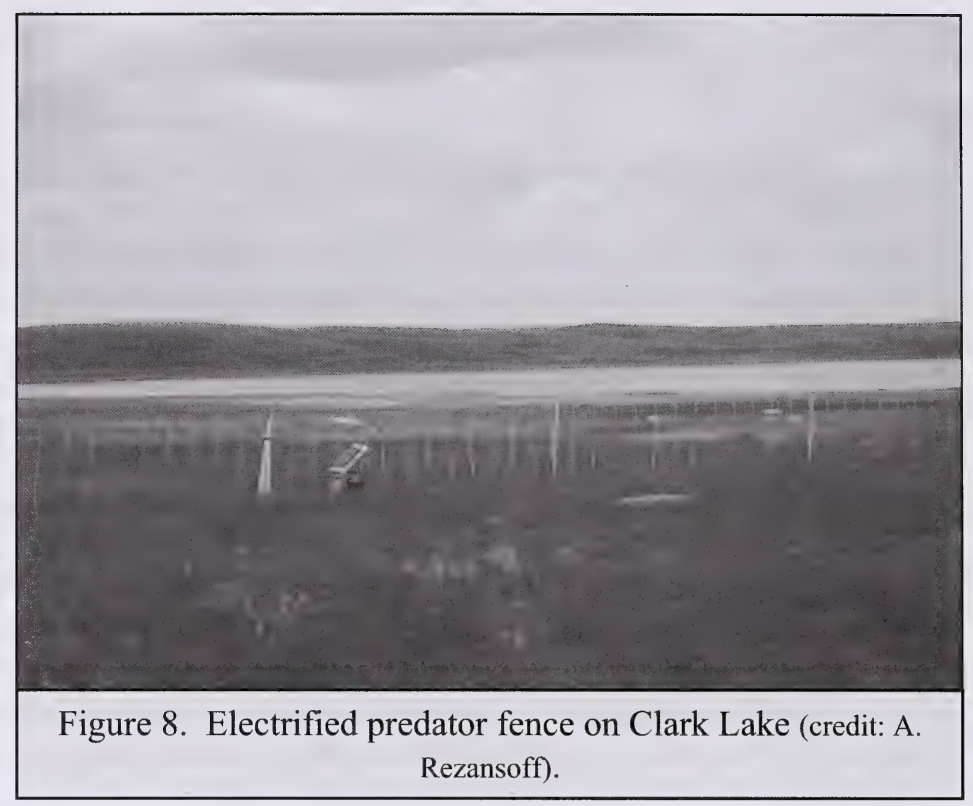
approximately 350 stick nests from trees surrounding Killarney and Reflex Lakes. Removal of old nests was intended to reduce the availability of nesting sites for merlins, which have occasionally caused significant mortality of adult piping plovers in Alberta (Michaud and Prescott 1999, Murphy et al. 2003b).

\subsection{HABITAT MANAGEMENT AND PROTECTION}

\subsection{Protective Notations}

In Alberta, piping plovers only occur on lakeshore habitats, and all shorelines known to be occupied by plovers in this province are under crown ownership (Wells et al. 2002). Applications for activities on crown land, such as industrial, residential or recreational development are referred to the Lands Division of Alberta Sustainable Resource Development for input. Alberta Fish and Wildlife Division, and other agencies with resources of interest (such as endangered species) on a particular unit of crown land, can apply for protective notations (PNTs) in the Land Standing Automated System (LSAS) database, so that their interest can be brought to the attention of land managers when applications for development are received. This process is the key means of ensuring that habitat for piping plovers is given strong consideration when developments are planned. Protective notations are not available on lands administered by the Special Areas Board, where many of the province's piping plovers occur. However, a parallel system, whereby notations can be placed in the Special Areas Management System (SAMS), offers similar benefits.

Alberta Fish and Wildlife has sought to apply notations on all crown lands where piping plovers have been know to occur since 1991. Particular emphasis has been placed on securing notations 
for all areas recognized as critical habitat under the federal Species at Risk Act, which includes 43 quarter-sections of land on 13 lakes (see Alberta Piping Plover Recovery Team 2006).

Prior to the Alberta Piping Plover Recovery Plan, 2005-2010, 39 PNTs and 34 SAMs for piping plovers had been established at 16 lakes for a total of 73 quarter sections, 29 of which were subsequently deemed to be critical habitat segments (Table 6). Since the 2005-2010 recovery plan, notations have been added to 42 quarter sections on 16 lakes where they were previously absent. We also added notations to 58 quarter sections on 12 lakes where adjacent quarter sections had approved notations. There are now a total of 173 protective notations on 32 lakes in Alberta, including all 43 quarter sections on 13 lakes that are recognized as critical habitat under the Species at Risk Act (Table 6).

Table 6. Summary of protective notations (PNTs or SAMS) applied to piping plover nesting areas prior to 2005, and during implementation of the 2005-2010 recovery plan. The number of notations placed on quarter sections listed as critical habitat under the federal Species at Risk Act is also shown.

\begin{tabular}{|c|c|c|c|c|c|c|c|}
\hline Lake & $\begin{array}{c}\text { PNT } \\
<2005\end{array}$ & $\begin{array}{c}\text { PNT } \\
2005-10\end{array}$ & $\begin{array}{l}\text { \#critical } \\
\text { quarters }\end{array}$ & Lake & $\begin{array}{c}\text { PNT } \\
<2005\end{array}$ & $\begin{array}{c}\text { PNT } \\
2005-10\end{array}$ & $\begin{array}{l}\text { \#critical } \\
\text { quarters }\end{array}$ \\
\hline Akasu & 1 & 3 & 1 & Junction & 0 & 3 & 0 \\
\hline Albert & 0 & 2 & 0 & Killarney & 11 & 5 & 5 \\
\hline Baxter & 4 & 1 & 1 & Leane & 0 & 2 & 0 \\
\hline Birch & 7 & 4 & 3 & Little Fish* & 4 & 3 & 4 \\
\hline Chain $\# 1^{*}$ & 0 & 1 & 0 & McLaren & 0 & 4 & 0 \\
\hline Chain \#3* & 0 & 1 & 0 & Metiskow & 1 & 0 & 0 \\
\hline Chain \#4* & 6 & 0 & 2 & Muriel & 2 & 16 & 3 \\
\hline Chain $\# 6^{*}$ & 0 & 1 & 0 & Piper & 1 & 1 & 2 \\
\hline Cipher & 0 & 4 & 0 & Plain & 0 & 2 & 0 \\
\hline Clark & 0 & 2 & 0 & Red Deer & 2 & 2 & 2 \\
\hline Dowling* & 14 & 10 & 10 & Rider & 0 & 2 & 0 \\
\hline Foster* & 0 & 4 & 0 & Rockeling Bay & 0 & 1 & 0 \\
\hline Frog & 0 & 7 & 0 & Sam & 1 & 0 & 0 \\
\hline Handhills* & 10 & 7 & 5 & Sunken & 3 & 2 & 1 \\
\hline Hansman & 0 & 3 & 0 & West & 0 & 3 & 0 \\
\hline Horseshoe & 3 & 0 & 0 & West Reflex & 3 & 4 & 4 \\
\hline
\end{tabular}

* denotes lakes in Special Areas (SAMS notations administered by the Special Areas Board); all other notations are protective notations (PNTs) in the Land Standing Automated System (LSAS) administered by the Lands Division of Alberta Sustainable Resource Development.

\subsection{Critical Habitat Designation and Protection}

Critical Habitat is defined under the federal Species at Risk Act as "the habitat that is necessary for the survival or recovery of a listed wildlife species and that is identified as the species' critical habitat in a recovery strategy or in an action plan for the species" (Environment Canada 2004). Candidates for critical habitat designation were identified for Alberta in the Alberta Piping 
Plover Recovery Plan, 2005-2010 (Alberta Piping Plover Recovery Team 2006), based on the frequency and magnitude of use of particular quarter sections of land by plovers in the province. The list includes 43 quarter sections of crown shoreline on 13 lakes in the province. These candidate lands were eventually identified in the national recovery strategy for the circumcinctus subspecies (see Environment Canada 2006, 2007), and the criteria for identifying them was adopted for use across the prairies.

SARA requires that lands designated as critical habitat be afforded "effective protection" against destruction. While there has been some lack of clarity on what constitutes "effective protection", we have actively sought to maintain a high quality of plover habitat on critical parcels (as well as on all other plover habitat in Alberta) through a variety of means. These include cooperative agreements with landowners, fencing and off-site watering, designation of sanctuaries, application of protective notations, cautionary and interpretive signage, information and extension activities, and augmentation of nesting substrates. Activities specific to critical habitat areas in Alberta are detailed in Table 7. Additional activities are summarized on a lake-by-lake basis (Section 7.0).

It is important to note that many plover habitats are quite remote, and free from most anthropogenic threats. Therefore, many habitats do not require actions such as fencing, signage and other tools that are employed where threats are relatively high. In these cases, the use of protective notations, and a positive relationship with adjacent landowners is generally sufficient to ensure protection of plover habitat.

\subsection{Industrial Referrals}

Protective notations (PNTs) or notations in the Special Areas Management System (SAMS) are the primary means whereby the presence of piping plovers is made known to land managers (i.e., Lands Division of Alberta Sustainable Resource Development and the Special Areas Board) and developers. Through the referral process, Fish and Wildlife Division staff can then provide input on practices that will reduce or eliminate possible conflicts with plover management.

It is difficult to quantify the number of recent industrial applications and referrals that apply directly to the management of plover habitat in Alberta. Whereas some referrals result from formal applications for development, others are informal or casual (predevelopment inquiries). Such inquiries may be directed to a variety of different people (regional or headquarters staff, area biologists or species specialists). Some applications refer to areas that are potentially, but not confirmed to be, plover habitat. Also, an unknown number of applications are not forwarded to Alberta Fish and Wildlife Division for comment. Regardless, there have been at least 50 applications for development on at least 20 lakes in the past five years that could have impacted piping plovers. These applications include seismic surveys, oil and gas well drilling, pipeline construction and gravel extraction.

Biologists usually seek to maintain distance or timing setbacks (see Table 8, Alberta Sustainable Resource Development 2009) to ensure no disturbance to nesting birds, and no permanent 
Table 7. Measures in place to maintain or improve habitat quality and quantity for piping plovers on 43 quarter sections of shoreline designated as critical habitat under the federal Species at Risk Act (SARA). See Section 7.0 for additional details.

\begin{tabular}{|c|c|c|c|c|c|c|c|c|}
\hline Lake & Segment ${ }^{1}$ & $\begin{array}{l}\text { PNT/ } \\
\text { SAMS }\end{array}$ & $\begin{array}{c}\text { Other } \\
\text { Notation }^{2}\end{array}$ & $\begin{array}{l}\text { Shoreline } \\
\text { Fence }\end{array}$ & Sanctuary & $\begin{array}{l}\text { Interpretive } \\
\text { Signage }\end{array}$ & $\begin{array}{l}\text { Cautionary } \\
\text { Signage }\end{array}$ & Other \\
\hline Akasu & A & $\mathrm{Y}$ & $\mathrm{Y}$ & $\mathrm{Y}$ & & & & \\
\hline Baxter & A & $\mathrm{Y}$ & $\mathrm{Y}$ & Y & & & & \\
\hline \multirow[t]{3}{*}{ Birch } & A & Y & $\mathrm{Y}$ & & & & & \\
\hline & B & Y & & Y & & & & \\
\hline & $\mathrm{C}$ & Y & & $\mathrm{Y}$ & & & & \\
\hline \multirow[t]{2}{*}{ Chain \#4 } & A & Y & & Y & & & & \\
\hline & B & Y & & Y & & & & \\
\hline \multirow[t]{10}{*}{ Dowling } & A & Y & & & & & & \\
\hline & B & Y & & & & & & \\
\hline & $\mathrm{C}$ & Y & & & & & & \\
\hline & D & Y & & & & & & \\
\hline & E & Y & & Y & & & & \\
\hline & $\mathrm{F}$ & Y & & Y & & & & \\
\hline & G & Y & & & & & & \\
\hline & $\mathrm{H}$ & Y & & & & & & \\
\hline & I & Y & & & & & & \\
\hline & $J$ & Y & & & & & & \\
\hline \multirow[t]{5}{*}{ Handhills } & A & $\mathrm{Y}$ & & $\mathrm{Y}$ & & $Y^{4}$ & & \\
\hline & B & Y & & Y & & $Y^{4}$ & & \\
\hline & $\mathrm{C}$ & Y & & & & $\mathrm{Y}$ & & \\
\hline & D & Y & & Y & & $Y^{4}$ & & \\
\hline & E & $\mathrm{Y}$ & & Y & & $\mathrm{Y}^{4}$ & & \\
\hline \multirow{5}{*}{ Killarney } & A & Y & Y & Y & & & & \\
\hline & B & Y & Y & $\mathrm{Y}$ & & & & \\
\hline & $\mathrm{C}$ & Y & & Y & & & & \\
\hline & D & Y & Y & & & & & \\
\hline & E & Y & Y & Y & & & & \\
\hline \multirow[t]{4}{*}{ Little Fish } & A & $\mathrm{Y}$ & & Y & & $\mathrm{Y}^{4}$ & & \\
\hline & B & $\mathrm{Y}$ & & Y & & $Y^{4}$ & & \\
\hline & $\mathrm{C}$ & $\mathrm{Y}$ & & Y & & $\mathrm{Y}^{4}$ & & \\
\hline & D & $\mathrm{Y}$ & & Y & & $Y^{4}$ & & \\
\hline \multirow[t]{3}{*}{ Muriel } & A & Y & & & Y & $\mathrm{Y}^{4}$ & Y & \\
\hline & B & $\mathrm{Y}$ & & & Y & $Y^{4}$ & Y & \\
\hline & $\mathrm{C}$ & Y & & & Y & $\mathrm{Y}^{4}$ & Y & \\
\hline \multirow[t]{2}{*}{ Piper } & A & $\mathrm{Y}$ & & $\mathrm{Y}^{3}$ & & & & \\
\hline & B & $\mathrm{Y}$ & & $\mathrm{Y}^{3}$ & & & & \\
\hline \multirow{2}{*}{ Red Deer } & A & Y & Y & Y & & & Y & \\
\hline & B & Y & & Y & & & $\mathrm{Y}$ & Gravel added \\
\hline Sunken & A & Y & & & & & & \\
\hline \multirow[t]{4}{*}{ W. Reflex } & A & $\mathrm{Y}$ & & Y & & $\mathrm{Y}^{4}$ & & \\
\hline & B & $\mathrm{Y}$ & Y & Y & & $Y^{4}$ & & \\
\hline & $\mathrm{C}$ & $\mathrm{Y}$ & $\mathrm{Y}$ & Y & & $\mathrm{Y}$ & Y & Vehicle barrier \\
\hline & D & Y & Y & Y & & $\mathrm{Y}^{4}$ & Y & \\
\hline
\end{tabular}

\footnotetext{
${ }^{1}$ Segment refers to the shoreline of individual quarter sections of land declared to be "critical"

${ }^{2}$ Includes other types of notations that may protect habitat quality, including: Heritage Rangeland, Licence of Occupation, Lakeshore Protection, and Flood Hazard Area

${ }^{3}$ Temporary electric fence

${ }^{4}$ Interpretive signs at nearby access points (different quarter section)
} 
alteration of habitat. In some circumstances, developers are requested to hire qualified biologists to conduct pre-development surveys for the presence of piping plovers. There are no known instances where developments have been denied due to the presence of plovers, nor any occasions where impacts on plovers or their habitats have been reported. Overall, the referral process has been very effective at protecting piping plover habitat in Alberta.

Table 8. Table of setback guidelines for the piping plover (adapted from Alberta Sustainable Resource Development 2009). These guidelines are used in the industrial referral process (see Section 6.3) to minimize disturbance to nesting birds and prevent habitat alteration.

\begin{tabular}{|c|c|c|c|c|c|}
\hline \multirow{2}{*}{ Species } & \multirow{2}{*}{ Wildlife Key Areas } & \multirow{2}{*}{$\begin{array}{l}\text { Restricted Activity } \\
\text { Dates }\end{array}$} & \multicolumn{3}{|c|}{$\begin{array}{l}\text { Setback Distances by } \\
\text { Land Use Activity }\end{array}$} \\
\hline & & & Low & Medium & High \\
\hline \multirow{2}{*}{ Piping plover } & \multirow{2}{*}{$\begin{array}{c}\text { Active nest, exposed bed } \\
\text { and shore }\end{array}$} & Apr 15 - Jul 31 & $100 \mathrm{~m}$ & $200 \mathrm{~m}$ & $200 \mathrm{~m}$ \\
\hline & & Aug 1 - Apr 14 & $50 \mathrm{~m}$ & $50 \mathrm{~m}$ & $200 \mathrm{~m}$ \\
\hline
\end{tabular}

\subsection{LAKE-SPECIFIC MANAGEMENT}

A wide variety of management activities have been employed to benefit plovers and their habitat. Some of these are common to all lakes: PNTs/SAMS notations (see Section 6.1), inventories (Section 4.1), application of predator exclosures (Section 5.1), and personal visits to landowners and leasees (Section 8.0). Other activities, related primarily to the direct improvement or protection of nesting habitat, are done on a site-specific basis, depending on local threats, land tenure, willingness of landowners to cooperate, and anticipated benefits. This section describes some of the key enhancement activities that have been completed in Alberta, with focus on those activities occurring during implementation of the Alberta Piping Plover Recovery Plan, 2005-2010. Some projects completed prior to initiation of the current recovery plan are listed, because maintenance of these projects has been ongoing through the duration of the current plan. Many of the projects were supported with financial assistance from the Habitat Stewardship Program for Species at Risk (Environment Canada), and were negotiated by staff from the Alberta Conservation Association.

Akasu Lake - Akasu Lake is one of the most consistently occupied piping plover lakes, with up to 16 birds occurring in some years. In 2005, a written agreement was signed with an adjacent landowner to fence $1.5 \mathrm{~km}$ of shoreline to prevent damage from cattle. The fence was erected by the landowner with supplies purchased by the plover recovery program. Approximately 25 ha of shoreline habitat was protected by this fence. 
Baxter Lake - Approximately $1.5 \mathrm{~km}$ of fencing was erected through an agreement with a local landowner in 2005. This fence protects $5 \mathrm{~km}$ of shoreline, and $42 \mathrm{ha}$ of nesting habitat on the lake.

Beaverhill Lake - A shoreline fence spanning four quarter-sections of land was erected to protect nesting habitat along the east shore of Beaverhill Lake in 2002. In addition, an existing crown grazing lease was amended to specify the timing and intensity of grazing on shorelines. The project was a collaboration between Alberta Sustainable Resource Development, Alberta Conservation Association, Ducks Unlimited Canada, and a grazing leaseholder. Approximately $3.5 \mathrm{~km}$ of fence was erected to protect 95 ha of shoreline.

Birch Lake - A written agreement with an adjacent landholder was signed in 2003 to erect a fence along the south shore of Birch Lake. The fence protects $3 \mathrm{~km}$ of shoreline and approximately 40 ha of habitat that was subsequently declared to be "critical" under the federal Species at Risk Act.

Clark Lake - A written agreement was signed with a local landowner in 2004 to erect $2.2 \mathrm{~km}$ of shoreline fence that protects 22 ha of shoreline on the east side of the lake.

Freshwater Lake - This lake, which occurs $1 \mathrm{~km}$ across the Saskatchewan border from Alberta, and in close proximity to several key Alberta lakes (West Reflex, Killarney, Cipher), is regularly monitored by crews from Alberta. The lake is consistently used by plovers, and has a long history of cattle disturbance. Staff from the Alberta Conservation Association and Alberta Fish and Wildlife Division worked with the Saskatchewan Watershed Authority and local leaseholders to negotiate a deal to erect $1 \mathrm{~km}$ of fence in 2004 . This fence, in conjunction with other existing fences in the area, eliminated cattle disturbance from $4 \mathrm{~km}$ and 60 ha of shoreline.

Handhills Lake - Handhills Lake has supported some of the largest populations of plovers ever recorded in Alberta ( 88 adults in 1988), but many areas of the lake have been severely impacted by cattle activity in the past.

Limited fencing to mitigate cattle damage was erected in the mid-1990s. In 2002, renewed efforts to work with local landowners were initiated. In that year, $1.4 \mathrm{~km}$ of shoreline was fenced in the east side of the lake, in partnership with the Handhills Hutterite Brethren. In 2003 , three additional fencing projects protected $3.1 \mathrm{~km}$ of shoreline, and an off-site watering project equipped with solar pumps were completed. In 2004, $1.5 \mathrm{~km}$ of fence was erected to protect approximately 15 ha of nesting habitat. In 2004, an agreement was signed with the Handhills Rodeo grounds to erect interpretive signage that was intended to inform local stakeholders about the management occurring on Handhills Lake, and to minimize disturbance to shorelines during the annual summer rodeo. A second shoreline fencing agreement with the Handhills Hutterite Brethren was signed in 2006. This fence was completed in 2008, and protected approximately $2.4 \mathrm{~km}$ of shoreline and 28 ha of nesting habitat. Total fencing on Handhills Lake is currently about $13 \mathrm{~km}$, with approximately 41 ha of shoreline nesting habitat being protected. Virtually all of Handhills Lake is now protected from cattle disturbance. 
Hansman Lake - Hansman Lake has had sporadic piping plover use since 2001. In the summer of 2004, a small interpretive sign was erected at a rest area on the southwest shore of the lake along Highway 13 (Figure 9).

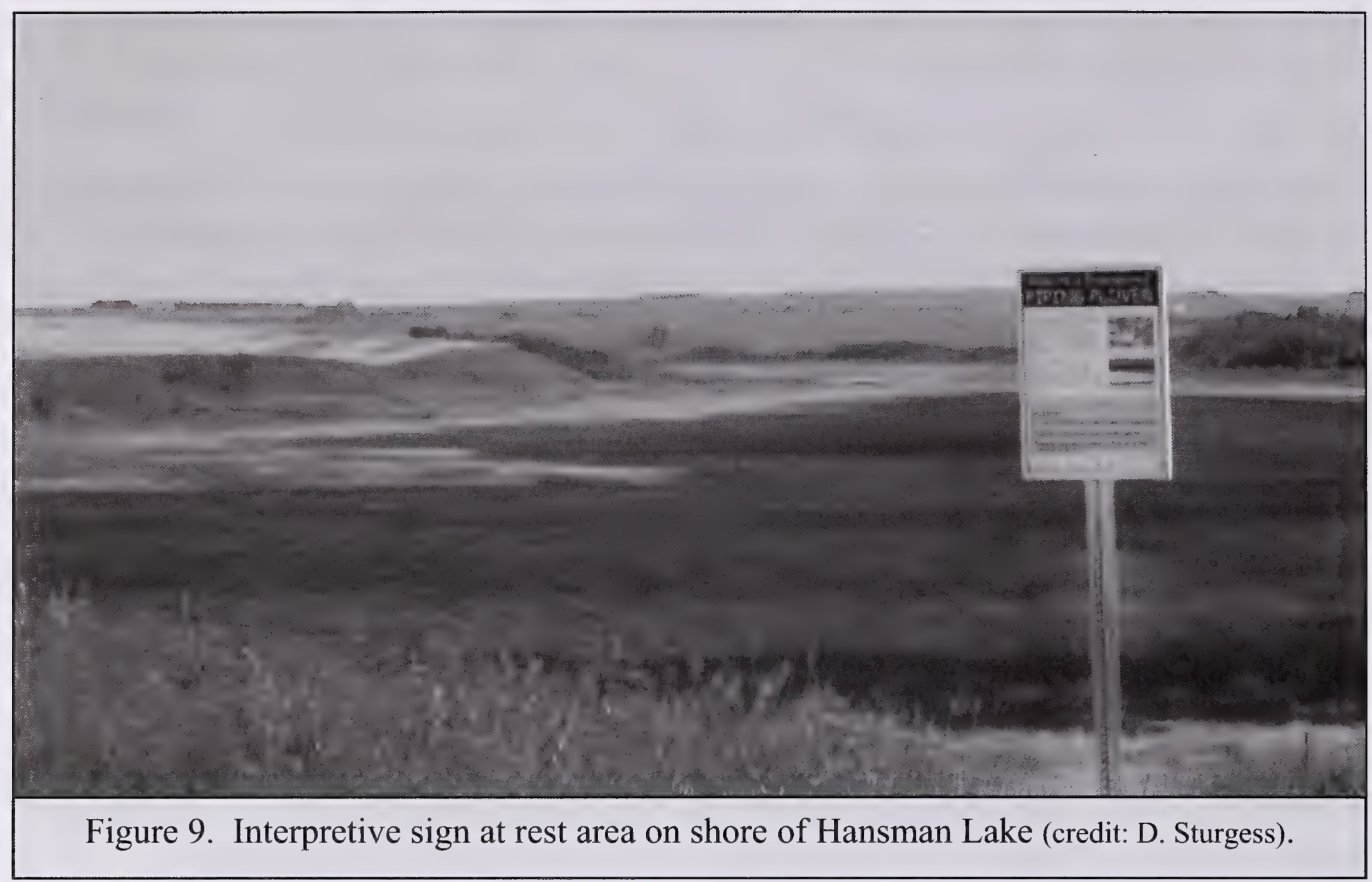

Killarney Lake - Killarney Lake has supported as many as 48 piping plovers (1994), but occasionally becomes dry. A joint fencing project involving Ducks Unlimited Canada and the Government of Alberta took place in the mid-1990s. Since then, two separate fencing projects have occurred on the lake. In 2006, a written agreement was reached with a private land owner to fence along one quarter section of land, and the project was completed in 2007. In 2008, a permanent cross fence was erected on the southern shore of the lake in partnership with Alberta Tourism, Parks and Recreation. These fences protect approximately $1.7 \mathrm{~km}$ of shoreline from cattle in an adjacent quarter section and the upland.

Little Fish Lake - Little Fish Lake was one of the earliest lakes targeted for plover management in Alberta, with several fencing and watering projects being completed in the early 1990s. In recent years, the water level on Little Fish Lake has retreated substantially, and fences erected in the past eventually excluded cattle from grazing in vegetated areas that were well away from the shore. In 2003, agreements were reached with local land owners to erect cross fencing and allow late summer/early fall grazing of vegetated shorelines. These agreements have been highly successful, and have been renewed in each subsequent year. In 2004, during a period of extended drought, the plover management team also provided water to a landowner to replenish a dugout that was now dry, to honor a commitment made in 1992 during initial management activities on the lake. Interpretive signage erected at Little Fish Lake Provincial Park in the 1990s was updated and replaced in 2004, in partnership with Alberta Tourism, Parks and Recreation. 
McLaren Lake - A written agreement was signed with a local landowner in 2004 to erect 2.1 $\mathrm{km}$ of shoreline fence that protects 25 ha of shoreline on the south side of the lake (Figure 10).

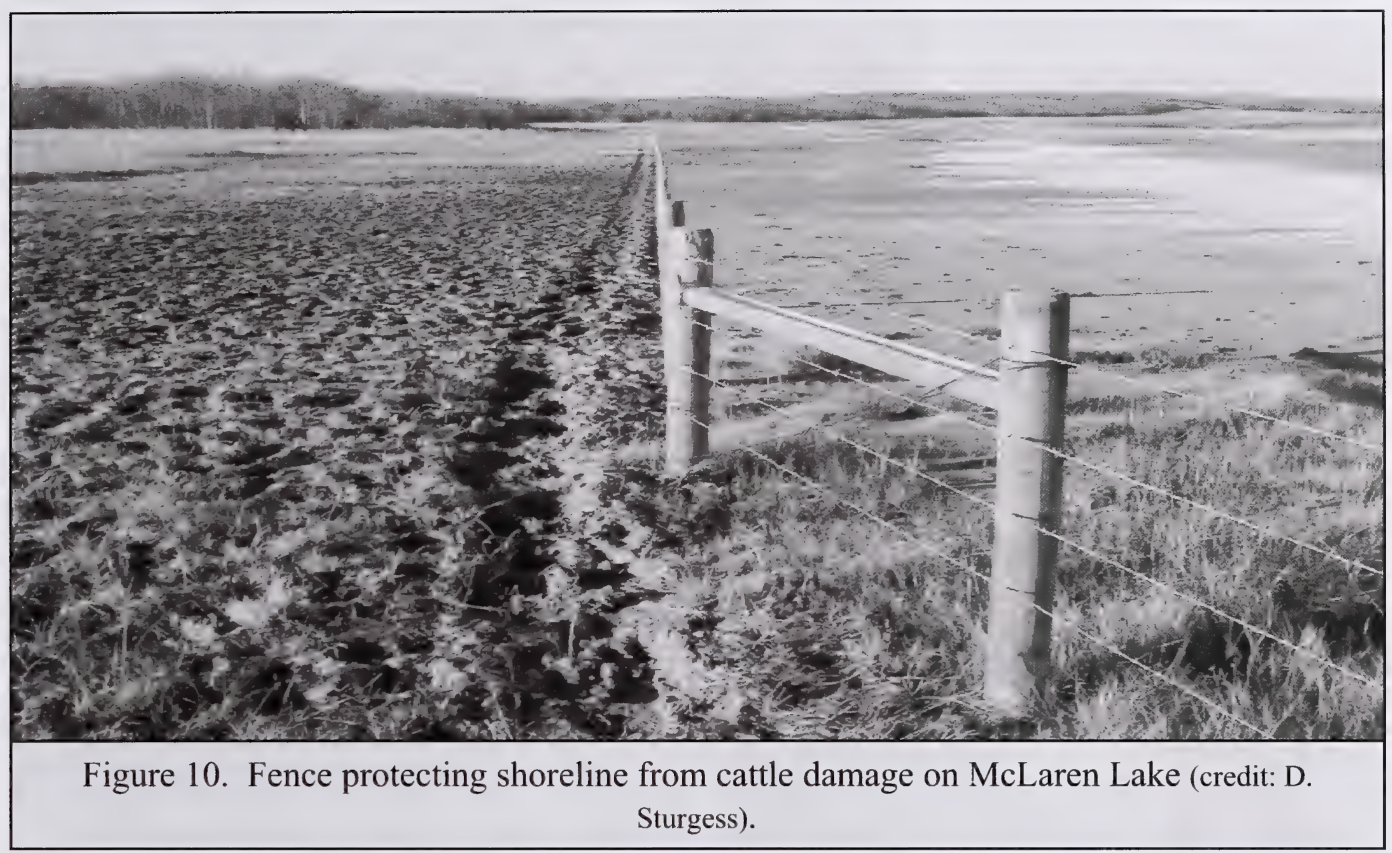

Muriel Lake - Receding water levels have exposed significant amounts of gravel habitat on Muriel Lake in the past decade. As a result, the lake has become one of the most important piping plover lakes in the province, with populations reaching a high of 46 birds in 2006 . The lake has a significant number of cottages, and the Alberta Fish and Wildlife Division established a seasonal wildlife sanctuary in 2003 to protect 630 ha of habitat on newly emerged islands and peninsulas in the south part of the lake. Field crews periodically conduct visits to cottagers to educate lake users about plover management, and to promote compliance with sanctuary restrictions (see also Section 8.0). These visits have been supplemented with an open house, periodic newsletters, and interpretive signage. The public has consistently shown a high level of support for the management of plovers on Muriel Lake.

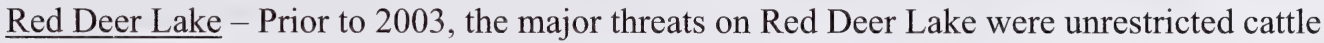
access to shorelines where plovers were nesting, and oil and gas development. Over the next few years, cooperative agreements were signed with three different landowners, and three separate fencing projects were completed. A fourth fence, voluntarily erected by one of the cooperating landowners, protects a stretch of beach where plovers nested for the first time in 2009. In total, $4.0 \mathrm{~km}$ of fence now protects all known nesting habitat on Red Deer Lake. Liaison with several oil companies has meant that new developments (two wells, a compressor station, and associated pipelines) are well above the high water mark. 
According to local landowners, water levels on Red Deer Lake (as of 2009) have receded to 60 -year lows. Receding shorelines have resulted in vegetation encroachment on most shores. In 2003, we experimented with the provision of nesting substrates by spreading 80 $\mathrm{m}^{3}$ of gravel on the beach. Plovers nested on this gravel five times over the next four years until vegetation encroached on this created habitat. Approximately four times as much gravel was applied in 2007, but further recession of the water meant that this substrate is currently too far from the

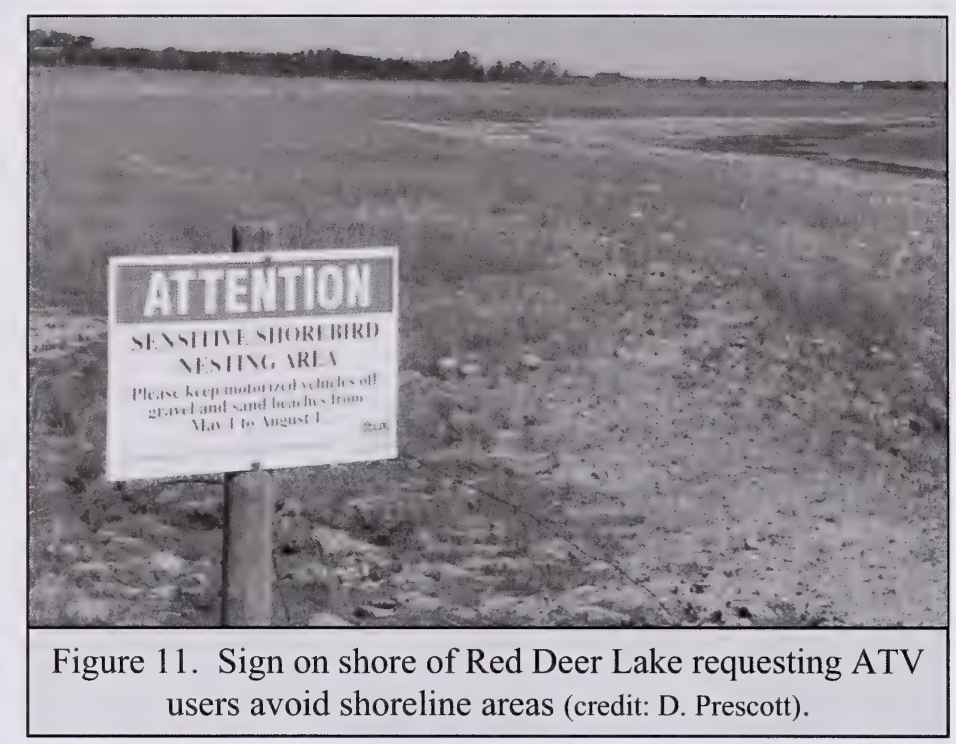
water for nesting.

In the past five years, ATV use of shorelines on Red Deer Lake has been an increasing problem. Maintaining cross fences to restrict shoreline access has been a challenge with receding water, and signage asking ATV users to avoid sand and gravel areas has been ineffective (Figure 11). In 2009, new signs with a more aggressive message were erected to help deter ATV use. These signs were ignored, and damage continued. New measures to contain this disturbance are being considered.

West Reflex Lake - West Reflex Lake, which straddles the Alberta-Saskatchewan border is one of the few plover lakes in Alberta that has never been dry since plover monitoring began in the 1980s. As a result, it one of the few lakes in Alberta to support nesting plovers with certainty on a year-to-year basis.

In 2003, modifications were made to a boat launch area to prevent vehicles from accessing nearby nesting habitat. In 2004, $2 \mathrm{~km}$ of fence was erected on the Saskatchewan side of the lake, in collaboration with the Saskatchewan Watershed Authority and the Manitou Cattle Grazers Cooperative. In 2005, $1.6 \mathrm{~km}$ of fence, and a cattle (Texas) gate was installed on the Alberta side of the lake to control cattle access to the shoreline. An annual shoreline grazing program, consisting of deferred grazing and exclusionary electric fencing around important feeding areas, was also put in place.

\subsection{INFORMATION AND OUTREACH}

Piping plovers were one of the first species to be intensively managed under Alberta's Species at Risk Program. The timing of the inaugural recovery plan (2002-2004) corresponded to a period when there was keen interest and concern from the public, landowners and industry 
about species at risk and their management. Consequently, there were numerous requests and opportunities to present information on plover management in Alberta. During implementation of the latest plan, public concerns about species at risk have decreased, and we have spent less time pursuing opportunities to make presentations to interest groups. However, opportunities to talk to naturalist groups, academia, and provincial/ federal government bodies were acted upon when available, and at least six presentations were made since 2005.

Most extension activities are geared toward individual landowners or cottager groups, where support for local management activities is both desirable and necessary. In a typical year, 20-30 landowners are contacted to secure access across lands, to maintain cooperative agreements, or to exchange information. An annual newsletter (Alberta Piping Plover Review; Figure 12), targeted towards these stakeholders, has been produced for the past four years and has been well received. A special newsletter, written specifically for cottage owners on Muriel Lake, was produced and distributed in 2004 and 2006.

Information for the general public is also provided through departmental websites (Fish and Wildlife Division, Alberta Conservation Association, and the Endangered Species Conservation Committee), and on various Environment Canada sites (SARA Public Registry,

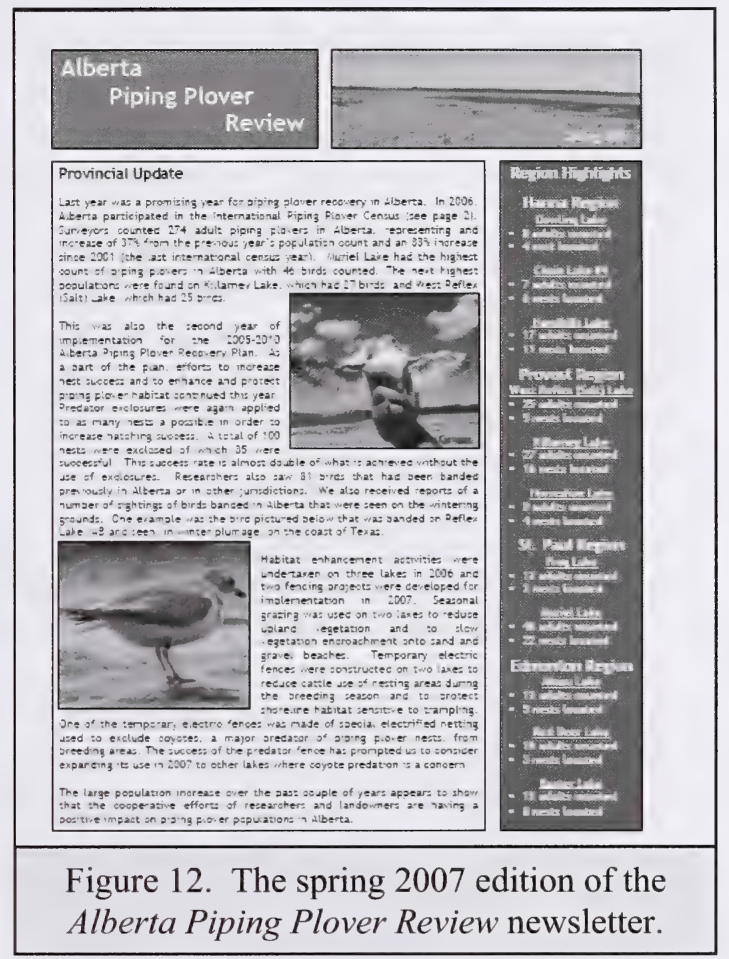
Canadian Wildlife Service). The industrial referral process provides opportunity for industry to become informed about plovers and their management. Occasional (6-10 per year) inquiries received from the public through the Alberta Connect portal, or directly to the Team Leader, are responded to each year. Interpretive signs, erected prior to implementation of the current plan, are maintained on several lakes (Gooseberry, West Reflex, Dillberry, Handhills, Little Fish, Miquelon, Muriel) where public use of shorelines is common.

In 2005, 2006 and 2009, staff of the Alberta Conservation Association and a private contractor conducted extensive surveys of cottagers on Muriel Lake, to gauge the support for, and interest in plover management on a key lake in the province. Similar surveys were also conducted in 2002 and 2003. These surveys show continuing high $(>90 \%)$ support for management activities, which included establishment of a seasonal sanctuary on the lake in 2003.

Finally, attempts are made to engage staff from within government and non-government organizations in the field program to give them "hands on" experience with plover management activities. Most notable is the involvement of biologists from the main delivery 
agencies (Fish and Wildlife and Alberta Conservation Association), staff of the Department of National Defence (Western Area Training Centre), as well as Conservation Officers and seasonal staff from Alberta Tourism, Parks and Recreation, and Fish and Wildlife Officers from Alberta Sustainable Resource Development.

\subsection{SYTHESIS AND OUTLOOK}

This report marks the conclusion of implementation of the Alberta Piping Plover Recovery Plan, 2005-2010. All of the activities listed in the Plan were completed (see Appendix 1), with a single exception: we did not conduct any aerial surveys to identify new plover habitat in the province. This activity was deemed unnecessary, as virtually all of the available plover habitat is known to wildlife managers, and because annual field work is sufficient to monitor shifts in habitat suitability and availability within the species' provincial range.

Through implementation of this plan, the preceding Alberta Piping Plover Recovery Plan 2002-2004 (Alberta Piping Plover Recovery Team 2002), and through work done in late 1990s and early 2000s without support of a formal plan, we have achieved several key accomplishments:

- Improvement in habitat quality to the point where virtually all key habitat in the province is protected from cattle disturbance (through cooperative agreements) and industrial development (through the referral process and use of protective notations)

- Large increases in productivity through the use of predator exclosures, and various predator deterrence tactics. Productivity exceeded target values of 1.25 chicks/pair/year in only two of five years. However, the overall value achieved between 2005 and 2009 (1.19 chicks/pair/year) is a conservative estimate, and real productivity values likely met or exceeded target values in most years

- Completion of annual inventories that provide reasonably accurate provincial population estimates, and allow for close monitoring of habitat conditions so that management can be directed to areas with the greatest impact

- Development of a successful working relationship with industrial developers, wherein no industrial developments have been hampered by the presence of plovers, and no plover habitat has been disturbed or destroyed

- High levels of protection achieved in all areas of Alberta that have been declared to be critical habitat under the federal Species at Risk Act

- Information and extension activities have increased public awareness of plover management, and all concerns about access on or through private land have now been resolved.

Despite these successes, we have so far been unable to achieve the provincial population goal of 300 birds. Given that populations in 2008 ( 295 birds) were close to target levels, we are 
confident that management goals can be achieved with continued effort. However, persistence of a healthy population in Alberta will require that management be continued or intensified in the future. For example, habitat quality can only be sustained through active maintenance of cooperative relationships, and the upkeep of infrastructure such as fences, signs and watering systems. Furthermore, we have little control over populations of predators that thrive in anthropogenic environments (coyotes, foxes, gulls, crows, skunks), and any reduction in the use of nest exclosures will have obvious consequences for population size of plovers in this province. Finally, human use of shorelines will accelerate as population growth increases. This will occur through increasing recreational demands for lakefront property, and the increasing use of all-terrain vehicles (ATVs) on plover beaches. ATV activity has resulted in substantial habitat damage at several localities, including the destruction of nests. The noticeable increase in ATV activity in the past five years, and the inability of fencing and signage to keep motorized traffic away from plover habitat is an increasing concern.

We have been encouraged by the generosity of funding partners, and by the cooperation of landowners, lessees and industrial interests in plover management. The long-term persistence of plover populations will require the ongoing participation and support of these players, as demands on the landscape increase. In early 2010 , an updated recovery plan for the piping plover will be drafted to guide recovery efforts for the next five or more years. Given the success of past actions, it is unlikely that many new initiatives will be proposed in the new plan. However, we suggest that increased emphasis be placed in maintaining strong relationships with previous co-operators so that past successes are not lost.

\subsection{LITERATURE CITED}

Alberta Piping Plover Recovery Team. 2002. Alberta piping plover recovery plan, 20022004. Alberta Sustainable Resource Development, Fish and Wildlife Division, Alberta Species at Risk Report Recovery Plan No. 2, Edmonton, AB. 21 pp.

Alberta Piping Plover Recovery Team. 2005. Implementation of the Alberta piping plover recovery plan, 2002-2004: final program report. Alberta Sustainable Resource Development, Fish and Wildlife Division, Alberta Species at Risk Report No. 99, Edmonton, AB. 19 pp.

Alberta Piping Plover Recovery Team. 2006. Alberta piping plover recovery plan, 20052010. Alberta Sustainable Resource Development, Fish and Wildlife Division, Alberta Species at Risk Recovery Plan No. 10. Edmonton, AB. 27 pp.

Alberta Sustainable Resource Development. 2009. Piping plover (Charadrius melodus). Pp. 65-70 in Restricted activity periods and setback guidelines for the protection of sensitive wildlife species within grassland and parkland natural regions of Alberta. Alberta Sustainable Resource Development, Fish and Wildlife Division, Calgary, AB. 170 pp.

Bjorge, R. R. 1997. The 1996 International Piping Plover Census in Alberta. Pp. 158-163 in 1996 International Piping Plover Census (J.H. Plissner and S.M. Haig, eds.). U.S. Geological Survey-Biological Resources Division, Corvallis, OR. 231 pp. 
Elliott-Smith, E., and S. M. Haig. 2004. Piping plover (Charadrius melodus), The Birds of North America Online (A. Poole, ed.). Cornell Laboratory of Ornithology, Ithaca, NY. http://bna.birds.cornell.edu/bna/species/002.

Elliott-Smith, E., S. M. Haig, and B. M. Powers. 2009. Data from the 2006 International Piping Plover Census. U.S. Geological Survey Data Series 426, Corvallis, OR. 332 pp.

Engley, L., and R. Schmelzeisen. 2002. Alberta piping plover predator exclosure and population monitoring program. Alberta Conservation Association, Edmonton, AB. 22 pp.

Engley, L., D. Prescott, and R. Schmelzeisen. 2004. Alberta piping plover predator exclosure and population monitoring program. 2004 field season report. Alberta Conservation Association, Edmonton, AB. 29 pp.

Environment Canada. 2004. Federal policy discussion paper: critical habitat. Environment Canada, Ottawa, ON. http://www.sararegistry.gc.ca/document/dspHTML_e.cfm?ocid=626\#2.

Environment Canada. 2006. Recovery strategy for the piping plover (Charadrius melodus circumcinctus) in Canada. Species at Risk Act Recovery Strategy Series. Environment Canada, Ottawa, ON. 30 pp.

Environment Canada. 2007. Addendum to the final recovery strategy for the piping plover (Charadrius melodus circumcinctus) in Canada. Environment Canada, Ottawa, ON. 12 pp.

Goossen, J. P., D. L. Amirault-Langlais, E. Elliott-Smith, and S. M. Haig. 2010. Piping plover conservation in Canada (2001-2006) in The 2006 International Piping Plover Census in Canada (J. P. Goossen and D. L. Amirault-Langlais, eds.). Technical Report Series No. 490. Canadian Wildlife Service (Environment Canada), Edmonton, AB and Sackville, NB. $158 \mathrm{pp}$.

Haig, S. M., and J. H. Plissner. 1992. 1991 International Piping Plover Census. Report to Division of Endangered Species, U.S. Fish and Wildlife Service Region 3, Fort Snelling, MN. 186 pp. + appendices.

Haig, S. M., and J. H. Plissner. 1993. Distribution and abundance of piping plovers: results and implications of the 1991 international census. Condor 95:145-156.

Haig, S. M., C. L. Ferland, F. J. Cuthbert, J. Dingledine, J. P. Goossen, A. Hecht, and N. McPhillips. 2005. A complete species census and evidence for regional declines in piping plovers. J. Wildl. Manage. 69:160-173.

Hofman, D. E. 1994. The 1991 piping plover census in Alberta. Pp. 43-47 in The 1991 International Piping Plover Census in Canada (S. P. Flemming, ed). Can. Wildl. Serv. Occ. Paper No. 82. 59 pp.

Larson, M. A., M. R. Ryan, and B. G. Root. 2000. Piping plover survival in the Great Plains: an updated analysis. J. Field Ornithol. 71:721-729. 
Larson, M. A., M. R. Ryan, and R. K. Murphy. 2002. Population viability of piping plovers: effects of predator exclusion. J. Wildl. Manage. 66:361-371.

Melvin, S. M., L. H. MacIvor, and C. R. Griffin. 1992. Predator exclosures: a technique to reduce predation at piping plover nests. Wildl. Soc. Bull. 20:143-148.

Michaud, I., and D. Prescott. 1999. Use of predator exclosures to protect piping plover nests in Alberta and Saskatchewan: 1999 field season report. Alberta Conservation Association, Edmonton, AB. 9 pp. + appendices.

Maslo, B., and J. L. Lockwood. 2009. Evidence-based decisions on the use of predator exclosures in shorebird conservation. Biol. Conserv. 142:3213-3218.

Mayer, P. M., and M. R. Ryan. 1991. Electric fences reduce mammalian predation on piping plover nests and chicks. Wildl. Soc. Bull. 19:59-63.

Murphy, R. K., R. J. Greenwood, J. S. Ivan, and K. A. Smith. 2003a. Predator exclusion methods for managing endangered shorebirds: are two barriers better than one?

Waterbirds 26:156-159.

Murphy, R. K., I. M. G. Michaud, D. R. C. Prescott, J. S. Ivan, B. J. Anderson, and M. L. French-Pombier. 2003b. Predation on adult piping plovers at predator exclosure cages. Waterbirds 26:150-155.

Prescott, D. R. C. 1997. Status of the piping plover (Charadrius melodus) in Alberta. Alberta Environmental Protection, Wildlife Management Division, Wildlife Status Report No. 1, Edmonton, AB. 19 pp.

Prescott, D. R. C. 2001. The 2001 International Piping Plover Census in Alberta. Alberta Sustainable Resource Development, Fish and Wildlife Division, Alberta Species at Risk Report No. 27, Edmonton, AB. 15 pp.

Prescott, D. 2009. The 2006 International Piping Plover Breeding Census in Alberta. Pp. 271-276 in Data from the 2006 International Piping Plover Census (E. Elliott-Smith, S. M. Haig, and B. M. Powers, eds.). U.S. Geological Survey Data Series 426, Corvallis, OR. 332 pp. http://pubs.usgs.gov/ds/426/pdf/ds426.pdf.

Rezansoff, A., R. Schmelzeisen, L. Engley, and D. Prescott. 2006. Alberta piping plover predator exclosure and population monitoring program. Alberta Conservation Association, Edmonton, AB. 41 pp.

Rezansoff, A., L. Engley, and D. Prescott. 2008. Alberta piping plover predator exclosure and population monitoring program. 2008 field season report. Alberta Conservation Association, Sherwood Park, AB. 47 pp. 
Rezansoff, A., L. Engley, and D. Prescott. 2009. Alberta piping plover predator exclosure and population monitoring program. 2009 field season report. Alberta Conservation Association, Sherwood Park, AB. 32 pp.

Richardson, I. M. 1997. Guidelines for the use of predator exclosures to protect piping plover (Charadrius melodus) nests. Alberta Environmental Protection, Wildlife Management Division, Edmonton, AB. 21 pp.

Richardson, I. M. 1999. Predator exclosures: a management technique to increase piping plover reproductive success in the Canadian prairies. M. Sc. Thesis, University of Alberta, Edmonton, AB. 65 pp.

Rimmer, D. W., and R. D. Deblinger. 1990. Use of predator exclosures to protect piping plover nests. J. Field Ornithol. 61:217-223.

Schmelzeisen, R., and L. Engley. 2003. Alberta piping plover predator exclosure and population monitoring program. Alberta Conservation Association, Edmonton, AB. 26 pp.

Schmelzeisen, R., L. Engley, A. Rezansoff, and D. Prescott. 2005. Alberta piping plover predator exclosure and population monitoring program. Alberta Conservation Association, Edmonton, AB. 35 pp.

van Huystee, S., R. Schmelzeisen, L. Engley, and D. Prescott. 2007. Alberta piping plover predator exclosure and population monitoring program. Alberta Conservation Association, Edmonton, AB. 44 pp.

Wells, M., M. Piorecky, and D. Prescott. 2002. Identification of historical and current quarter-section use by piping plovers in Alberta. Unpubl. rept., Alberta Fish and Wildlife Division, Red Deer, AB. 5 pp.

Wershler, C., and C. Wallis. 1987. Status of the piping plover in Alberta 1986. Unpubl. rept. For World Wildlife Fund Canada-Wild West Program. Canadian Wildlife Service and Alberta Fish and Wildlife, Edmonton, AB. 54 pp. 


\section{APPENDIX 1: IMPLEMENTATION SCHEDULE AND COSTS (from Alberta Piping Plover Recovery Plan, 2005-2010)}

\begin{tabular}{|c|c|c|c|c|c|c|c|c|}
\hline \multirow{2}{*}{$\begin{array}{l}\text { Recovery } \\
\text { Plan } \\
\text { Section } \\
\end{array}$} & \multirow[t]{2}{*}{ Action } & \multirow{2}{*}{$\begin{array}{c}\text { Lead } \\
\text { Agency }\end{array}$} & \multicolumn{5}{|c|}{ Cost (thousands/year) } & \multirow[t]{2}{*}{ Total } \\
\hline & & & 2005-06 & 2006-07 & 2007-08 & 2008-09 & 2009-10 & \\
\hline 8.1 & $\begin{array}{l}\text { Habitat Management \& } \\
\text { Protection }\end{array}$ & & & & & & & \\
\hline 1. & Notations/landowner contact & 1,2 & 3 & 3 & 3 & 3 & 3 & 15 \\
\hline 2. & Liaison in industrial referral system & 1 & * & * & * & $*$ & * & $*$ \\
\hline 3 . & Cooperative agreements & 2 & 10 & 10 & 10 & 10 & 10 & 50 \\
\hline 4. & Implement habitat improvement & 1,2 & 50 & 50 & 50 & 50 & 50 & 250 \\
\hline 5 . & Monitor critical habitat & 1,2 & 3 & 3 & 3 & 3 & 3 & 15 \\
\hline \multirow{2}{*}{6.} & \multirow[t]{2}{*}{ Monitor managed habitat } & \multirow[t]{2}{*}{1,2} & 3 & 3 & 3 & 3 & 3 & 15 \\
\hline & & & 69 & 69 & 69 & 69 & 69 & 345 \\
\hline 8.2 & Productivity Enhancement & & & & & & & \\
\hline 1. & Predator exclosure project & 2 & 40 & 40 & 40 & 40 & 40 & 200 \\
\hline 2. & Predator deterrent measures & 2 & 2 & 2 & 2 & 2 & 2 & 10 \\
\hline \multirow[t]{2}{*}{3.} & \multirow{2}{*}{ Annual report } & \multirow[t]{2}{*}{1} & 2 & 2 & 2 & 2 & 2 & 10 \\
\hline & & & 44 & 44 & 44 & 44 & 44 & 220 \\
\hline 8.3 & Information \& Outreach & & & & & & & \\
\hline 1. & Presentations & 1,2 & * & * & * & * & * & * \\
\hline 2. & Contact with cooperators & 2 & 3 & 3 & 3 & 3 & 3 & 15 \\
\hline \multirow[t]{2}{*}{3.} & \multirow[t]{2}{*}{ Annual newsletter } & \multirow[t]{2}{*}{1} & 2 & 2 & 2 & 2 & 2 & 10 \\
\hline & & & 5 & 5 & 5 & 5 & 5 & 25 \\
\hline 8.4 & $\begin{array}{l}\text { Population Monitoring \& } \\
\text { Research }\end{array}$ & & & & & & & \\
\hline 1. & Population monitoring & 1,2 & 25 & 25 & 25 & 25 & 25 & 125 \\
\hline 2. & International Census & 1 & 0 & 10 & & & & 10 \\
\hline 3. & Aerial surveys & 1 & 5 & 1 & 1 & 1 & 1 & 9 \\
\hline 4. & Habitat rating system & 1,2 & 2 & & & & & 2 \\
\hline 5. & Remote predator surveillance & 1,2 & 1 & 5 & * & * & * & 6 \\
\hline 6. & Banding & 1,2 & * & * & * & * & * & * \\
\hline \multirow[t]{2}{*}{7.} & \multirow{2}{*}{ Cooperate with other initiatives } & \multirow[t]{2}{*}{ All } & * & * & * & * & * & * \\
\hline & & & 33 & 41 & 26 & 26 & 26 & 152 \\
\hline 8.5 & $\begin{array}{l}\text { Plan Management \& } \\
\text { Administration }\end{array}$ & & & & & & & \\
\hline 1. & Annual recovery team meeting & All & 1 & 1 & 1 & 1 & 1 & 5 \\
\hline 2. & Evaluate recovery actions & All & * & * & * & * & * & * \\
\hline 3. & Liaison with other plover initiatives & 1 & * & * & * & * & * & * \\
\hline 4. & Database management & 1 & 4 & 4 & 4 & 4 & 4 & 20 \\
\hline \multirow[t]{3}{*}{5.} & Annual report & 1 & 1 & 1 & 1 & 1 & 1 & 5 \\
\hline & \multirow[t]{2}{*}{ Overall Coordination } & \multirow[t]{2}{*}{1} & 18 & 18 & 18 & 18 & 18 & 90 \\
\hline & & & 24 & 24 & 24 & 24 & 24 & 120 \\
\hline 8.6 & Resource Acquisition & & & & & & & \\
\hline 1. & Funding securement & & 5 & 5 & 5 & 5 & 5 & 25 \\
\hline \multirow[t]{2}{*}{2.} & \multirow{2}{*}{ Staff training } & \multirow[t]{2}{*}{1,2} & 2 & 2 & 2 & 2 & 2 & 10 \\
\hline & & & 7 & 7 & 7 & 7 & 7 & 35 \\
\hline \multicolumn{3}{|c|}{ TOTAL } & 182 & 190 & 175 & 175 & 175 & 897 \\
\hline
\end{tabular}

Alberta Fish and Wildlife Division, ${ }^{2}$ Alberta Conservation Association 
For a list of additional reports in the Alberta Fish and Wildlife Division - Species at Risk Series please go to our website:

$\underline{\text { http://srd.alberta.ca/BioDiversityStewardship/SpeciesAtRisk/ProgramReports.aspx }}$ 
